\title{
Status of biodiversity in wetlands of Biswanath District of Assam, India
}

\author{
RANJIT KAKATI ${ }^{1}$, NIKU DAS ${ }^{2}$, ABHISHEK BHUYAN ${ }^{2}$, DIPANKAR BORAH ${ }^{3, \bullet}$ \\ ${ }^{1}$ Department of Zoology, Gauhati University, Guwahati 781014, Assam, India \\ ${ }^{2}$ Biswanath College. Biswanath 784176, Assam, India \\ ${ }^{3}$ Department of Botany, Goalpara College. Goalpara 783101, Assam, India. `email: dipankar.borah@goalparacollege.ac.in
}

Manuscript received: 3 December 2020. Revision accepted: 29 December 2020.

\begin{abstract}
Kakati R, Das N, Bhuyan A, Borah D. 2021. Status of biodiversity in wetlands of Biswanath District of Assam, India. Biodiversitas 22: 453-471. Reports on biodiversity of a region are the firsthand data to understand the assemblage, importance, and to follow conservation inputs. The present study was aimed to document and analyze the wetland biodiversity of Biswanath District of Assam, India. Data was collected from 27 wetland habitats from 2015-2019. A total of 235 taxa were recorded, of which 79 taxa (77 species, one variety, and one subspecies) were vascular plants, 83 water birds, 47 fishes, 7 amphibians, 18 reptiles, and 2 mammals. None of the plants and amphibians fall under any of the threatened categories as per IUCN Red List 2020. However, among the bird species, 2 species are assessed as endangered, 4 species as vulnerable, and 10 species as near threatened. Among the fishes, 2 are vulnerable and 3 near threatened. Among the reptiles one is extinct in the wild (EW), 3 endangered and 3 are vulnerable. Along with the checklist of the present biodiversity, past and present population trends, as well as earlier records from Assam of the threatened species, and near threatened species is provided. The results of this study can be used by stakeholders for species identification and as the baseline taxonomic account for future studies on the conservation of these wetland species in a global context.
\end{abstract}

Keywords: Assam, checklist, conservation, threatened, taxonomy, wetland

\begin{abstract}
Abbreviation: EW: Extinct in Wild, CR: Critically Endangered, EN: Endangered, VU: Vulnerable, NT: Near threatened, LC: Least concern, NE: Not evaluated, C: common (frequency of sighting was $75 \%$ out of the total visits in its respective habitats throughout the year or during their season of occurrence), O: occasional (frequency of sighting was 50-75\% out of the total visits in its respective habitats throughout the year or during their season of occurrence), U: uncommon (frequency of sighting was 25-50\% out of the total visits in its respective habitats throughout the year or during their season of occurrence), S: stray (frequency of sighting was less than $25 \%$ out of the total visits in its respective habitats throughout the year or during their season of occurrence), R: Widespread resident, r: Very local resident, W: Widespread winter visitor, w: Sparse winter visitor, s: Local summer breeder
\end{abstract}

\section{INTRODUCTION}

Wetlands are defined as transitional land between terrestrial and aquatic ecosystems where the water body is usually at or near the surface, or the land is covered by shallow water (Mitsch and Gosselink 1986). They are considered as one of the most productive ecosystems, providing a multitude of benefits to diverse forms of life (Sarma and Borah 2014). Apart from their critical role in maintaining human welfare, they also play important roles in the hydrological cycle and biodiversity conservation (Ramsar Convention Secretariat 2007). It also comprises about $40 \%$ of the existing plant and animal diversity (Zedler and Kercher 2005).

In India, wetlands have been used for recreational, religious, aesthetic, and economic uses (Prasad et al. 2002; Bassi and Kumar 2012). They are ecologically sensitive and adaptive systems (Turner et al. 2002) as well as support a huge diversity according to their geographical allocation, genesis, water regime, and chemistry (Space Applications Centre 2011). During dry periods they help to reserve water, thus keeping the water table high and relatively stable. During periods of flooding, they mitigate flood and trap suspended solids, and attached nutrients (Prasad et al. 2002).
According to Article 1.1 of the Ramsar Convention, a total number of 2165 Ramsar sites are identified globally and 27 of them are in India (Ramsar Secretariat 2013). As, per the Directory of Indian Wetlands (WWF and AWB 1993), about 67,420 numbers of small and large size wetlands are spread over 40,40,087 hectares of the country's landmass (Kumar et al. 2019). Northeast India, including Assam valley and adjacent hill ranges, exhibits a complex mosaic of vegetation types ranging from northern tropical wet evergreen to montane wet temperate types (Champion and Seth 1968). Located at the heart of Northeast India, the state of Assam has a different set of physiographical conditions from its surrounding regions and represents a diverse range of plant communities (Borah et al. 2020b). It has a geographical area of 7.84 million hectares which constitutes $2.39 \%$ of the country's total area. It is dominated by the Brahmaputra river which is around $2900 \mathrm{~km}$ in length and occupies a drainage area of about 9,35,500 sq. km (Islam and Rahmani 2004) forming several wetlands in all the corners of the state. In the present scenario agriculture, mining, municipal waste deposition, industrial waste drainage, constructions of roads, and other structures are the major threats to the wetland biodiversity of Assam as well as India. 
Biswanath District of Assam, India is very diverse in wetlands as is a part of the Brahmaputra-Kaziranga flood plains. Hence the area has several un-drained depressions: ox-bow lakes, swamps, permanent rivulets, etc. These are characterized under swamp forests and the dominant plants include Hygrorhiza aristata, Barringtonia acutangula, Phragmites karka, etc. (Kanjilal et al. 1934-1940). A very few numbers of works have been so far conducted in Biswanath District of Assam (Sarma et al. 2009a; Borah et al. 2018; 2019a,b; 2020a,b,c,d; 2021) and a single study by Barooah and Mahanta (2006) aimed to present the wetland flora of the region. In this present study, we aim to record the whole wetland biodiversity of Biswanath, Assam including both the floral and faunal elements.

\section{MATERIALS AND METHODS}

\section{Study area}

The study was conducted in the Biswanath District of Assam, India which is spread across the foothills of Eastern Himalaya (Islam and Rahmani 2004). The district encompasses two major forested areas, Kaziranga National Park in the southern boundary as well as Behali Reserve Forest on its northern boundary. It is bounded by the hilly terrains of Arunachal Pradesh, India on the north, alluvial plains of Nagaon and Golaghat districts on the south, east by Lakhimpur district and Sonitpur district on the west. The total human population is around 6,12,400 individuals (Govt. of Assam 2011) belonging to different ethnic communities like Chutiya, Kalita, Nepali, Bengali, Munda Bodo, Mishing, Karbi, etc. comprising the entire Assamese community (Saikia 2017). The total area of the region is about $1,100 \mathrm{sq} . \mathrm{km}$ and the elevation ranges between $65-$ $350 \mathrm{~m}$ asl. (Gogoi et al. 2020). It is a part of the flood plains of the river Brahmaputra, which traverses throughout the district and the soil type is mainly alluvial (Gogoi et al. 2020). The climate of the area is a humid subtropical type with an average temperature of $6^{\circ} \mathrm{C}$ to $34^{\circ} \mathrm{C}$ (Islam and Rahmani 2004) and the average rainfall is $2000 \mathrm{~mm}$ (Neog and Bordoloi 2016-2017).

\section{Data collection}

A total of 27 wetland habitats have been studied (Table 1, Figure 1), from 2015-2019. They were purposely selected for the assessment of total flora and faunal species.

The plant species were collected randomly following the methods of Jain and Rao (1977). The voucher specimens were later identified using different literature (Kanjilal et al. 1934-1940; Hooker 1872-1897) and matched at ARUN and ASSAM Herbaria. The specimens will be finally deposited in the Herbarium of Goalpara College, Department of Botany, Assam for future references. The correct nomenclature is updated using POWO (2019).

For the avifaunal species, data collection was carried out by walking (about $1-1.5 \mathrm{~km} / \mathrm{h}$ ) along the bank as well as traveling by boat (Gaston 1975; Bibby et al. 2000). All the surveys were carried out in the early morning (05:30 am-
08:30 am) and early evening (03:00 pm-6:00 pm) to correlate with birds' peak activity (Fisher and Hicks 2006). Nikon ACULON (a211-10-22x50) binoculars were used and each observation took 15 to 20 minutes. Birds were counted thoroughly and it was ensured that the same birds were not counted repeatedly. They were then identified by their photographs, primary song, and sight using Inskipp and Inskipp (1991), and Gill and Wright (2006), Grimmett et al. (2011). The residential status of the birds are classified as per Grewal and Bhatia (2014) and the vernacular names of the bird species were provided following Das and Mukherjee (1974) and Datta (2013).

Fishes were collected with the help of the local fisherman who used different kinds of fishing nets, traps, and local fishing techniques (Vishwanath 2017). The specimen were identified based on morphometric and anatomical studies, using Talwar and Jhingran (1991) and Vishwanath (2017).

Reptiles and amphibians were observed by visual encounter survey (Crump and Scott 1994), randomized walk (Lambert 1984), active searching (Rolfe and McKenzie 2000), and Pitfall trap (Heyer et al. 1994). Stream transects of $50 \times 2 \mathrm{~m}$ were laid randomly around the wetlands (Dutta et al. 2013). The specimen were later identified through Ahmed et al. (2009), Mathew and Sen (2010), Purkayastha (2013), and Saikia and Kharkongor (2017).

Table 1. Sites of data collection within Biswanath District of Assam, India

\begin{tabular}{|c|c|c|c|}
\hline $\begin{array}{l}\text { Site } \\
\text { no. }\end{array}$ & Plots & Coordinates & $\begin{array}{c}\text { Alt. } \\
\text { (masl.) }\end{array}$ \\
\hline$\overline{1 a}$ & Rowmari & N 26³9'39.07"; E 9257'11.07" & 68 \\
\hline $1 b$ & Kari & N 26³9'08.17"; E 9256'32.38" & 67 \\
\hline $1 \mathrm{c}$ & Hokoma & N 26ํ'ㄹ'30.16"; E 9255'37.12" & 70 \\
\hline $2 \mathrm{a}$ & Nagshankar & N 2643'29.05"; E 9259'39.46" & 76 \\
\hline $2 b$ & Shildubi & N 264ㅇ'34.36"; E 9257'30.37" & 67 \\
\hline $2 \mathrm{c}$ & Sukanpukhuri & 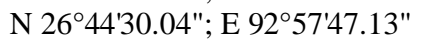 & 76 \\
\hline $3 a$ & Kodomoni & 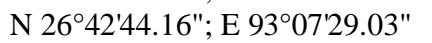 & 69 \\
\hline $3 b$ & Ogota & N 2642'26.18"; E 930ำ04.77" & 66 \\
\hline $3 \mathrm{c}$ & Kaori & N 2641'20.63"; E $93^{\circ} 1$ 1'52.54" & 68 \\
\hline $4 a$ & Kalidubi & N 264'16.6"; E 9316'31.9" & 82 \\
\hline $4 b$ & Dhondi & N 2651'02.71"; E 9342'39.81" & 74 \\
\hline $4 \mathrm{c}$ & Kharoi & N 2650'46.12"; E 934ㅇ'31.92" & 76 \\
\hline $5 \mathrm{a}$ & Kothaichuk & 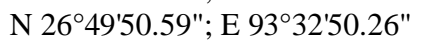 & 80 \\
\hline $5 b$ & Pavoigreen & N 26²8'57.06"; E 9309'10.53" & 87 \\
\hline $5 c$ & Biswanath Ghat & 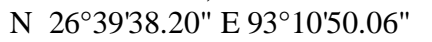 & 70 \\
\hline $6 a$ & Behali RF & N 265'ㄴ'54.34"; E 9315'06.41" & 110 \\
\hline $6 b$ & Kuwori & N 264'ㄴ'18.67"; E 930'19.74" & 83 \\
\hline $6 c$ & Borigaon & 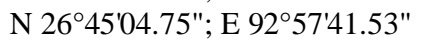 & 73 \\
\hline $7 \mathrm{a}$ & Dhenudhara & N 2640'20.38"; E 9309'39.19" & 80 \\
\hline $7 b$ & Gerekijan & 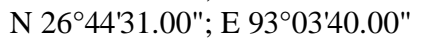 & 75 \\
\hline $7 \mathrm{c}$ & Chaiduar college & N 265'ㄴㄷ.35"; E9336'20.99" & 80 \\
\hline $8 \mathrm{a}$ & Burigang & 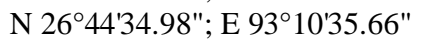 & 78 \\
\hline $8 b$ & Lehugaon & N 265'14.26"; E93ㅇ' 9'15.51" & 79 \\
\hline $8 \mathrm{c}$ & Botiamari & N 2646'54.00"; E93²6'11.84" & 78 \\
\hline $9 \mathrm{a}$ & Bamgaon & N 2644'25.52"; E 93ㅇ'53.47" & 79 \\
\hline $9 b$ & Kalyani Temple & N 2647'34.58"; E 9331'26.70" & 68 \\
\hline $9 \mathrm{c}$ & Gangmou & N 264'ㄴㄱ.28"; E 9319'27.22" & 66 \\
\hline
\end{tabular}




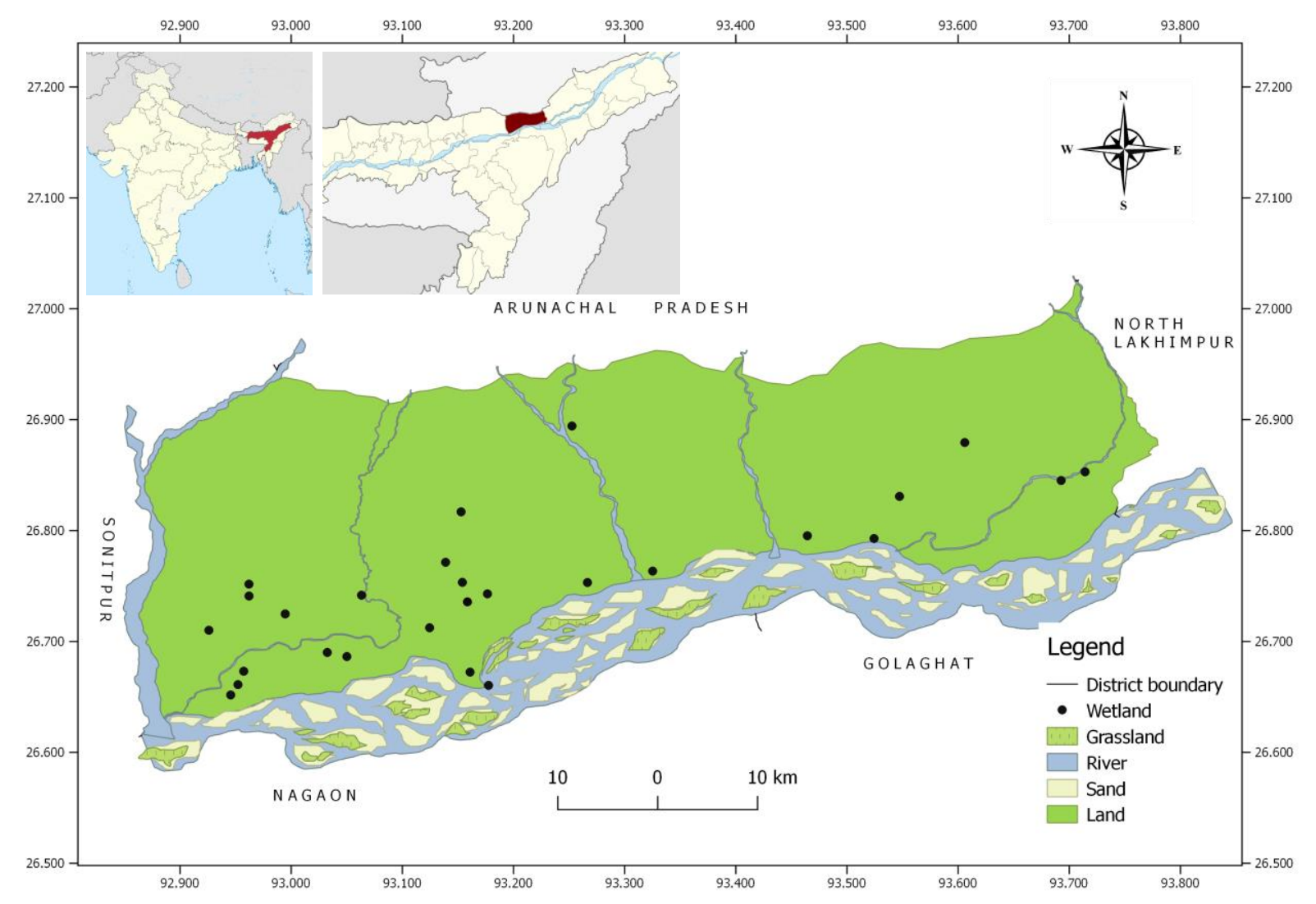

Figure 1. Wetlands of Biswanath District, Assam, India $\left(26^{\circ} 36^{\prime}\right.$ and $27^{\circ} 02^{\prime} \mathrm{N} ; 92^{\circ} 58^{\prime}$ and $\left.93^{\circ} 47^{\prime} \mathrm{E}\right)$

Turtle species data were observed by direct sighting, visual encounter survey (VES), and active searching method (Qaiser and Sharma 2016, Basumatary and Sharma 2013). Specimens were identified based on morphometric study and with the help of Ahmed et al. (2009) and Daniel (2016).

Mammal sightings were counted by direct observation and track count techniques (Khan et al. 2007). A total of 12 observation surveys of 2 hours by foot and boat were conducted (Mason and Macdonald 1986; Reuther et al. 2002).

The threat statuses of all the taxa are as per IUCN Red List (2020).

The Shannon diversity index of the faunal species was calculated for each wetland following Shannon and Weaver (1949). The floral elements were recorded randomly and hence the ecological study was avoided.

\section{RESULTS AND DISCUSSION}

A total of 79 taxa (77 species, one variety, and one subspecies) of vascular plants have been recorded falling under 60 genera and 39 families (Table 3). Linderniaceae was the dominant family with 9 species, followed by Commelinaceae (5 species) and so on. Genera wise Bonnaya and Ludwigia were the dominant ones with 3 species each. As per IUCN 2020, 14 plants are assessed and are under the least concern category, whereas the remaining 65 species were not evaluated

A total of 156 species of faunal elements were recorded. Out of them, 83 were water birds (Table 4 ), 47 were fishes (Table 5), 7 were amphibians (Table 6), 18 were reptiles (Table 7), and 2 were mammals (Table 8).

Among the 83 species of wetland bird species, 2 species are assessed as endangered (EN), 4 species as vulnerable (VU), and 10 species as near threatened (NT), and 67 species as least concern (LC) as per IUCN 2020. All these species fall under 22 families, among which most of them (19 spp.) were represented by Anatidae, followed by Ardeidae (10 spp.). Concerning the residential status of these avian taxa, 38 species were migratory birds and 45 species were residential. The number recorded in the present study is comparable to Chakdar et al. (2019) from Rajiv Gandhi Orang National Park (87 spp.) and Das and Deori (2010) from Nameri National Park (73 spp.), however less than Barua and Sharma (1999) from Kaziranga National Park (134 spp.).

Among the 47 fishes, Wallago attu and Cyprinus carpio are vulnerable; Ompokbi maculatus, Chitala chitala and Ailia coila are near threatened and other 42 species are assessed as least concern. These species fall under 21 families and Cyprinidae with $18 \mathrm{spp}$. was the most dominant. Many of them are important decorative ornamentals, viz. Puntius, Channa, Mystus, Macrognathus, etc., and Channa barca is one of the high valuable fish found in the region. All these fishes were recorded earlier from Assam (Dey and Kar 1989; Kar et al. 2007, 
Vishwanath 2017), but due to overfishing during the breeding season and filling of wetlands for agriculture, these species are presently facing a high risk of extinction. The number reported in the present study is however less, compared to the number reported by Ngasepam et al. (2015) from Sone beel, one of the largest wetlands of Assam (69 spp.). The larger area of Sone beel and its several inlets contributes to the reason for its high diversity. Moreover, most of the wetlands within our study area are manmade, 12 are natural and only two of them now exist without much disturbance.

Regarding the amphibians, all the species recorded in the present study are distributed throughout different parts of Assam mainly floodplain areas (Purkayastha et al. 2011; 2020; Sanghal et al. 2014), and are assessed as least concern as per IUCN 2020.

During the survey, a total of 18 reptile species were recorded of which 10 are turtles, 7 snakes, and one lizard. Nilssonia nigricans is already extinct in the wild (EW), three species were endangered viz., Chitra indica, Pangshura sylhetensis, and Geoclemys hamiltonii, two species were vulnerable viz., Nilssonia gangeticus and Nilssonia hurum; Cyclemys gemeli was not evaluated and others were under least concern (IUCN 2020). All turtles were found in Nagshankar Temple tank except Chitra indica which was observed in Botiamari wetlands. Almost all the snakes were under least concern, except Python bivittatus which is vulnerable. The number of amphibians and snakes reported in our study is less than Purkayastha (2020) reporting 22 species of amphibians reported from Amchang Wildlife Sanctuary), Purkayastha (2011) (28 snake species reported from Guwahati and Sahgal (2014) reporting 25 species of snakes reported from Kaziranga National Park. Considering the number of turtles, it is higher than Manipur central valley (Qaiser and Sharma 2016), reporting 5 species, but is less than Kaziranga National Park where 17 species was recorded by Basumatary and Sharma (2013) and 12 species in Rajib Gandhi Orang National Park by Deka and Saikia (2015).

A total of 10616 individuals of faunal species were recorded from 27 wetlands. Out of these, the highest, 2455 individuals were recorded from Rowmari beel and the lowest, 29 individuals were recorded from Chaiduar college tank. The Shannon diversity index ranged from 2.19 to 3.69 with species richness varying from 10 to 129 (Table 2). The highest diversity was found in Rowmari beel and the lowest diversity was found in Chaiduar college tank.

\section{Notes on the population of threatened species}

Greater adjutant stork, Leptoptilos dubius (EN)

Globally less than 1000 individuals of endangered Greater adjutant storks exists and is considered as the most endangered among the 20 species of storks present in the world (Birdlife International 2020). It is endemic to Nepal, Bangladesh, Myanmar, Cambodia, and Southern Vietnam and India. The Brahmaputra valley of Northeast India supports more than $80 \%$ (600-700 individuals) of its global population (Barman 2011). According to IUCN 2007 , only two potential breeding sites in the world exist, Assam (India) and Cambodia. Boragaon dumping ground area in Guwahati, India recorded the highest number (466) of individuals in a small area (Saikia and Bhattacharya, 1989a). During our survey, one individual was observed in the Hokoma tank on 12 February 2019 near Panpur, Kaziranga National Park, and another one was recorded in Rowmari beel. Habitat loss, poisoning, cutting down of nesting trees has resulted in a breeding failure and the population is in serious decline.

Earlier records from Assam: Dibru Saikhowa National Park (Islam and Rahmani 2004; Choudhary 1997), Pani Dihing Sanctuary (Saikia 1995; Rahmani et al. 1990), Majuli river island (Saikia 1995), Misamari, Sonitpur district (Saikia 1995), Burhachapori Wildlife Sanctuary (Choudhury 2000), Manas National Park (Scott 1989), Nalbari, Darrang district (Rahmani et al. 1990; Saikia 1995), Orang National Park, Darrang district (Rahmani et al. 1990; Changkakati and Das 1991), Kaziranga National Park (Scott 1989), Chakrashila Wildlife Sanctuary, Pabitora Wildlife Sanctuary (Choudhury 2000), Deepor Beel (Saikia and Bhattacharya 1989b; Barman et al. 1995), Sonapur, Nagaon (Saikia 1995), Bordoibam Bilmukh Sanctuary (Choudhury 2000), Laokhowa Wildlife Sanctuary (Rahmani et al. 1990; Choudhury 2000), Morigaon district (Saikia 1995), Nagaon and Sivasagar district (Changkakati and Das 1991; Choudhury 1993), Jhanjimuk-Kokilamukh, Jorhat (Mahanta et al. 2019).

\section{Pallas's fish eagle, Haliaeetus leucoryphus (EN)}

Pallas's fish eagle is a globally vulnerable species (Birdlife International 2020). It breeds in Central Asia between the Caspian and Yellow Seas, from Kazakhstan to Mongolia, China, and South to the Himalayas, Northern India, and Bangladesh. The main breeding populations are in China, Mongolia, and South Asia. The population is decreasing in China, Pakistan, India, Nepal, Bhutan, Myanmar, and Bangladesh due to habitat loss and climate change. The total population is likely to be less than 10,000 individuals (Birdlife International 2001) and in Asia, it is estimated about 2,500-9,999 mature adults (Birdlife International 2015). Assam hosts around 882 individuals (Ebird 2020). Only one individual was observed during the present survey on a tree near Karibeel, Kaziranga National Park Sixth edition.

Table 2. Shannon_H diversity index of faunal communities in different wetlands of Biswanath, Assam, India

\begin{tabular}{llllllllll}
\hline Wetland & $1 \mathrm{a}$ & $1 \mathrm{~b}$ & $1 \mathrm{c}$ & $2 \mathrm{a}$ & $2 \mathrm{~b}$ & $2 \mathrm{c}$ & $3 \mathrm{a}$ & $3 \mathrm{~b}$ & $3 \mathrm{c}$ \\
Shannon_H & 3.69 & 3.29 & 3.00 & 3.12 & 3.68 & 3.40 & 3.35 & 3.38 & 3.11 \\
Wetland & $4 \mathrm{a}$ & $4 \mathrm{~b}$ & $4 \mathrm{c}$ & $5 \mathrm{a}$ & $5 \mathrm{~b}$ & $5 \mathrm{c}$ & $6 \mathrm{a}$ & $6 \mathrm{~b}$ & $6 \mathrm{c}$ \\
Shannon_H & 3.55 & 3.56 & 2.97 & 3.31 & 3.14 & 2.96 & 3.46 & 3.17 & 3.48 \\
Wetland & $7 \mathrm{a}$ & $7 \mathrm{~b}$ & $7 \mathrm{c}$ & $8 \mathrm{a}$ & $8 \mathrm{~b}$ & $8 \mathrm{c}$ & $9 \mathrm{a}$ & $9 \mathrm{~b}$ & $9 \mathrm{c}$ \\
Shannon_H & 3.44 & 3.52 & 2.20 & 2.25 & 2.23 & 2.97 & 2.34 & 3.07 & 2.48 \\
\hline
\end{tabular}



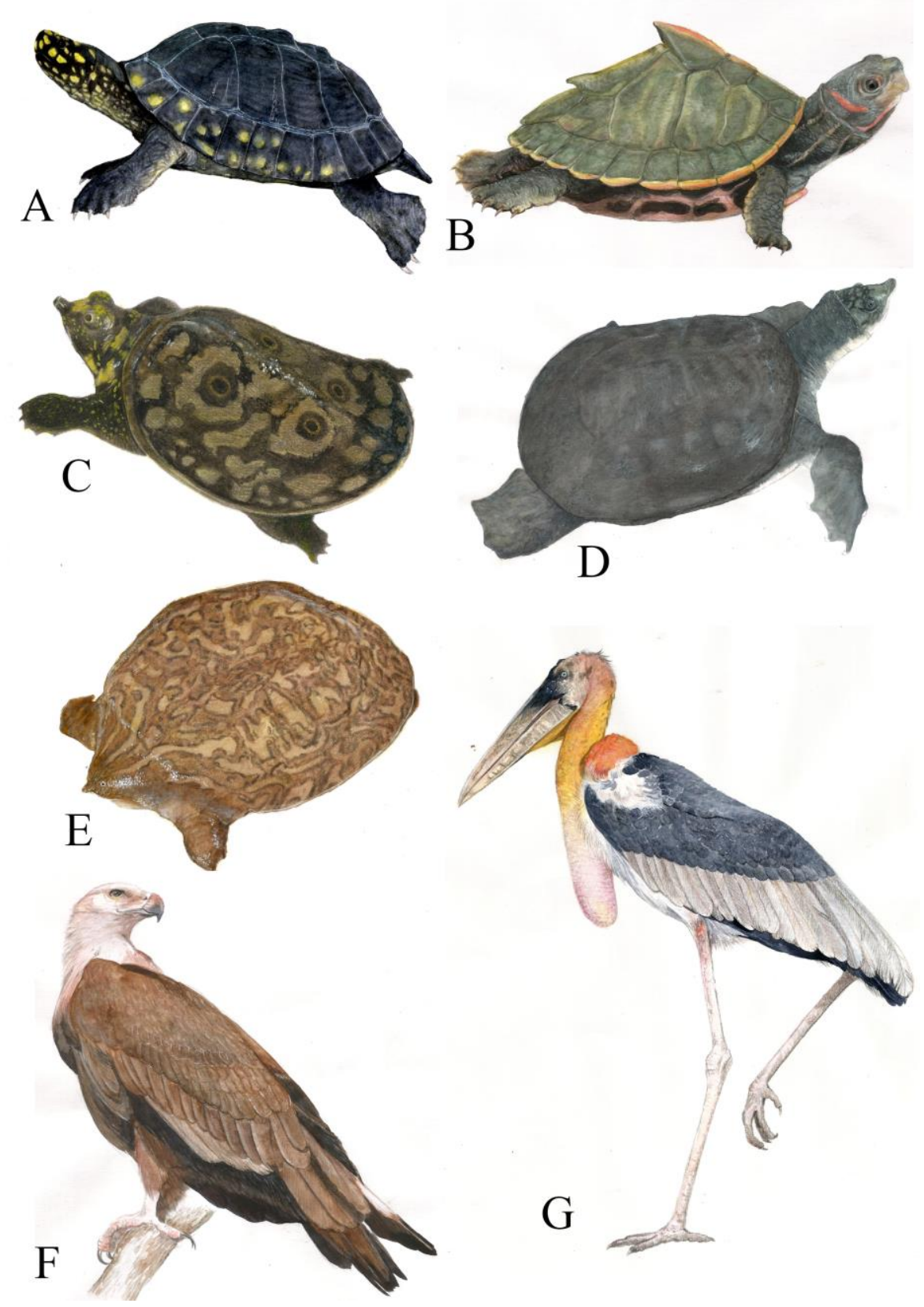

Figure 2. Illustrations of the endangered species of Biswanath, Assam, India: A. Geoclemys hamiltonii, B. Pangshura sylhetensis, C. Nilssonia nigricans, juvenile, D. Nilssonia nigricans, adult, E. Chitra indica, F. Haliaeetus leucoryphus, G. Leptoptilos dubius

Earlier records from Assam: Dibru-saikhowa National Park (Choudhury 2000; Islam and Rahmani 2004), Pani Dihing (Choudhury 1991; 2000), Nameri National Park (Talukdar and Das 1997), Manas National Park (Rahmani et al. 1988; Choudhury 2000), Kaziranga National Park (Samant et al. 1995; Barua and Sharma 1999), Deepor Beel (Barman et al. 1995; Choudhury 2000).

Swamp francolin, Francolinus gularis (VU)

Swamp francolin is distributed in the low-lying Terai belt that lies between the Himalayan foothills to the north and the Indo-Gangetic plains to the south, covering India, Bangladesh, and Nepal (Rahmani and Qamar 1993; Ali and Ripley 2007; McGowan et al. 1994, 1995; Javed et al.
1999; Shakya et al. 2001). They were recorded in 12 sites covering the entire Terai and Brahmaputra flood plains by Javed et al. (1999): 7 sites from Uttar Pradesh, 4 from Assam and one from Bihar. During our survey, two flocks were observed in wet alluvial grasslands on the bank of Rowmari-beel of Kaziranga national park and swamps of Behali Reserve Forest. Transformation of its habitat into agricultural land, hunting and trapping, and use of agricultural pesticides are the main threats to this species.

Earlier records from Assam: Kaziranga National Park (Baruah and Sharma 1999), Dibru-Saikhowa National Park (Choudhury 2006), Orang National Park (Chakdar et al. 2019), Jhanjimuk-Kokilamukh, Jorhat (Mahanta et al. 2019). 
Common pochard, Aythya farina ( $V U$ )

Common Pochard is a rare winter visitor to Assam. The total global population is estimated to be $22,00,000$ 25,00,000 individuals (BirdLife International 2020) and was earlier categorized as Least Concern, but reassessed as Vulnerable (IUCN, 2020). It is very rarely sighted in Assam, only in wetlands of three protected areas, so far: Kaziranga National Park, Orang National Park, and DibruSaikhowa National Park. The breeding range of this species spans across the temperate zones of Eurasia, South East Russia, and North China. It is also an irregular visitor to southern India (Ali and Ripley 2007; Rasmussen and Anderton 2005; Rahmani and Islam 2008; BirdLife International 2013). We recorded 19 individuals of this species in Rowmari-beel.

Earlier records from Assam: Kaziranga National park (Baruah and Sharma 1999), Orang National Park (Chakdar et al. 2019, Talukdar and Sharma 1995), Dibru Saikhowa National Park (Choudhury 2006), Jhanjimuk-Kokilamukh, Jorhat (Mahanta et al. 2019)

\section{Lesser adjutant stork, Leptoptilos javanicus (VU)}

Around 6,500-8,000 mature individuals of the lesser adjutant stork are left in the world. They are distributed in Cambodia, India, Malaysia, Nepal, Indonesia, Sri Lanka, Bangladesh, Myanmar, Laos, Bhutan, Brunei, Vietnam and Thailand (BirdLife International 2013). Cutting down their nesting trees, habitat destruction and the use of fertilizers and pesticides in agricultural land are threatening the survival of this species. A total of 47 individuals were observed in different sites during the study. Many nesting sites were also found within urban-scapes and near roadsides. The preferable species for hosting nests observed in the study were Bombax ceiba, Alstonia scholaris, and Carallia brachiata. But occasionally nests are also observed on Aegle marmelos and Mangifera indica.

Earlier records from Assam: Biswanath District (Chaudhury 2000), Dibru Saikhowa National Park (Islam and Rahmani 2004; Saikia 1995), Dum Duma (Saikia 1995), Jamjing beel (Choudhury 1992), Pani Dihing (Saikia 1995), Nameri National Park (Choudhury 1991), Majuli Island (Saikia 1995), Dikhoumukh (Saikia 1995), Borajan (Choudhury 1995), Manas National Park (Rahmani et al. 1988; Saikia 1995), Orang National Park (Saikia 1995), Kaziranga National park (Saikia 1995; Baruah and Sharma 1999), Laokhowa Wildlife Sanctuary (Kahl 1971; Saikia 1995), Nalbari (Saikia 1995), Chakrashilla Wildlife Sanctuary, Sareswar beel (Saikia 1995), Jengdia beel, Kamrup district (Saikia 1995), Pabitora Wildlife Sanctuary (Saikia 1995), Deepor beel (Saikia and Bhattacharya 1989; Barman et al. 1995), Jhanjimuk-Kokilamukh, Jorhat (Mahanta et al. 2019).

\section{Woolly-necked stork, Ciconiaepis copus (VU)}

It is a widespread tropical species breeding in Asia and Africa. They build their nest generally on tall trees located near agricultural lands or wetlands (Hancock 1992; Choudhary 2013; Rahmani 1996). Nesting in mobile towers in Pune is also been reported (Vaghela et al. 2015).
This species is also recorded from higher elevation areas above $3,790 \mathrm{~m}$ i.e. Napahai wetland, China (Burnham 2012), and from Annapurna Conservation Area, Nepal above 3,540 m (Ghale 2018). Generally found in small flocks, we observed 7 individuals in Rowmari-beel, 3 individuals in Kodomoni, and 2 individuals in Botiamari. A nesting site was also observed in Nagshankar, Biswanath which was recently felt down for road extension. As so far only a single nest was observed and it represents the direct threat humans are posing.

Earlier records from Assam: Dibru-saikhowa National Park (Choudhury 2006); Orang National Park (Chakdar et al. 2019), Kaziranga National Park (Baruah and Sharma 1999), Jhanjimuk-Kokilamukh, Jorhat (Mahanta et al. 2019), Nameri National Park (Das and Deori 2010).

\section{Wallago catfish, Wallago attu (VU)}

It is widely distributed in large parts of South and Southeast Asia. However, it is an example of a species with a discontinuous distribution (Roberts, 1982). The rivers of Assam: Brahmaputra, Barak, its tributaries, and many more wetlands and rivers are very good habitat for this species. We recorded this species from many wetlands namely Rowmari-beel, Kari-beel, Hokoma-beel, Shildubi-beel, Biswanath Ghat, Kodomoni-beel, Ogota-beel, Kawri-beel, Dhondi-beel, Kharoi, Kothaichuk, Pavoi green, Borigaon, Dhenudhara, Gereki-jaan, and Kalyani Temple tank.

Earlier records from Assam: Sone beel (Ngasepam et al. 2015), Kulsi River (Islam et al. 2013), an unspecified locality within Assam (Goswami et al. 2012; Goswami and Zade 2015; Baro et al. 2014; Das and Biswas 2009; Goswami et al. 2007; Talwar and Jhingran 1991; Sarmah et al. 2004).

\section{Common carp, Cyprinus carpio (VU)}

It is a widely distributed freshwater species found in Europe and Asia. This species was recorded from Rowmari beel, Pavoi greens, Kuwori pukhuri, and Dhondi beel.

Earlier records from Assam: Sone beel (Ngasepam et al. 2015), Kulsi River (Islam et al. 2013), an unspecified locality within Assam (Goswami et al. 2012; Goswami and Zade 2015; Baro et al. 2014; Das and Biswas 2009; Goswami et al. 2007; Talwar and Jhingran 1991; Sarmah et al. 2004).

\section{Black softshell turtle, Nilssonia nigricans (EW)}

The black softshell turtle is distributed throughout Asia, Africa, and New Guinea (Fritz and Peter 2007). In the year, 2002 it has been declared extinct in wild (IUCN 2002). And, presently can only be observed in some ex-situ conservation sites of the Brahmaputra basin and some of the temples of Bangladesh, such as Bayazid bostami shrine and Chittagong (Meylan 1987; Das et al. 2018). During our study, we found 34 individuals (20 mature individuals and recently 14 new hatchlings) of Black softshell turtle in Nagshankar which hosts a good population in a small pond compared to the other known localities.

Earlier records from Assam: Nagshankar temple tank (Kakati and Tamuli 2019), Mihi-beel, Kaziranga National Park (Basumatary and Sharma 2013; Sanghal 2014), 
Biswanath Ghat (Praschag and Gemel 2002), Rangamatiabeel (Agaratoli), Diffolu River at Diffolumukh camp, Sapekhati beel (near Gendarmari camp) and Bhengrai nullah (near Rongamatia camp) (Ahmed and Das 2009), Kamakhya Temple Pond, Nagshankar Pond, Dibrugarh, Tinsukia, Biswanath Ghat, Nameri National Park, Nazira (Prachag and Gemel 2002).

\section{Narrow-headed softshell turtle, Chitra indica (EN)}

It is distributed throughout South Asia, on the banks of rivers such as Brahmaputra, Indus, Ganga, Godavari, Jamuna, Meghna, Dholeswar, Coleroon, Mahanadi, and Padma in India, Bangladesh, Pakistan and Nepal and its connected wetlands (Das 1995; Choudhury 1990; Dutta 1997; Mirza and Ali 1972; Khan 2006; Akbar et al. 2006; Khan 1987; Rashid 1991; Rashid and Swingland 1997). During our study, one individual was recorded in Botiamari entangled in a fisherman's net.

Earlier records from Assam: Bhaisamari-beel (Basumatary and Sharma 2013), Debeswari, Arimora and Agaratoli, Kaziranga National Park (Ahmed and Das 2009; Sanghal 2014), Orang National Park (Deka and Saikia 2015), Fakirganj ferry Ghat, Dhubri (Datta 1997). Dibru Saikhowa National Park (Choudhury 1995), Kaziranga NP (Bhupathy et al. 1999; Choudhury 2004), Nameri National Park (Bhupathy et al. 1999).

\section{Assam roofed turtle, Pangshura sylhetensis (EN)}

The Assam roofed turtle is endemic to North-eastern India and Bangladesh (Das et al. 2010). It is a very small freshwater turtle with a hard shell, facing a high risk of extinction. It prefers half-submerged logs inclined at $10-45^{\circ}$ angle, and climb up to a height of 2-3 feet from the water surface (Kakati and Tamuli 2019). 7 individuals were recorded during our study.

Earlier records from Assam: Brahmaputra, Pachnoimukh, and Marisali (Deka and Saikia 2015), Arimora, Debeswari, Kaziranga National Park (Lahkar 2000; Sanghal 2014), Biswanath Ghat (Ahmed and Das 2009), Nagshankar Tank (Sarmah et al. 2009; Kakati and Tamuli 2019), Kolathua village, Sibsagar District, Garo Hills, Cachar (Moll 1987), Manas National Park (Sharma 1988), Banko Beel, Dibru Saikhowa National Park, Saikhowa Ghat, Ghilamara, Dhakuakhana, Roha beel, Ranganadi, Lakhimpur district (Choudhury 1995), Kukurmara and Chandubi (Choudhury et al. 1999).

\section{Indian softshell turtle, Nilssonia gangeticus (VU)}

It is an Indian endemic, distributed in the Indus, Ganga, Brahmaputra, Mahanadi, Kosi, and some other rivers across Peninsular India (Das 1995). 14 individuals were recorded in Nagshankar during our study and two individuals were recorded from Botiamari.

Earlier records from Assam: Kaziranga National Park (Basumatary and Sarma 2013; Sanghal 2014), Biswanath Ghat, Brahmaputra (Ahmed and Das 2009), Orang National Park (Deka and Saikia 2015), Nagshankar (Kakati and Tamuli 2019).
Indian peacock softshell turtle, Nilssonia hurum (VU)

It is a large-sized freshwater soft-shell turtle found mainly in Bangladesh, India, Nepal, and Pakistan. We recorded 17 individuals from Nagshankar.

Earlier records from Assam: Orang National Park (Deka and Saikia 2015), Mihi-beel KNP, Nagshankar (Kakati and Tamuli 2019), Arimora Bor-beel, Kaziranga National Park, Biswanath Ghat (Ahmed and Das 2009), Panigaon, Lakhimpur district (Choudhury 1995), Brahmaputra Basin, North Cachar (Dutta 1998), Kaziranga NP (Choudhury 2004), Pakke Wildlife Sanctuary (Dutta 1998), Kaziranga National Park (Sanghal 2014).

\section{Black pond turtle, Geoclemys hamiltonii (EN)}

The black pond turtle or Indian spotted turtle is a highly threatened freshwater turtle endemic to South Asia, Pakistan (Ganges and Indus river drainage), Northeast India (Assam), and Bangladesh (Fritz et al. 2017). We recorded a single individual in Nagshankar pond temple.

Earlier records from Assam: Orang National Park (Deka and Saikia 2015), Kaziranga National Park (Basumatary and Sharma 2013).

\section{Burmese python, Python bivittatus (VU)}

It is one of the largest snake species distributed across Southeast Asia (Barker and Barker 2008, 2010). It is invasive in USA (Breuer and Murphy 2009-2010). We recorded three individuals, one each in Biswanath Ghat, Nagshankar, and Behali Reserve Forest.

Earlier records from Assam: Guwahati (Purkayashta et al. 2011; 2020), Kaziranga National Park (Sanghal 2014).

Smooth-coated otter, Lutrogale perspicillata (VU)

It is distributed throughout South and Southeast Asia (Silva et al. 2015; Ismvael 2019). Records of it in higher elevational areas of the Himalayas are also present (Medhi et al. 2014). We recorded 5 individuals in the southern part of Rowmari-beel in two concurrent observations, 3 more individuals were also recorded in the Biswanath Ghat area of the Brahmaputra River.

Earlier records from Assam: Kaziranga National Park (Choudhury 2013; Sanghal 2014).

\section{Ganges River Dolphin, Platanista gangetica (EN)}

Locally known as 'Sishu' or 'Xihu' or 'Sihu' in the Brahmaputra valley and 'Susu' or 'Phoo' in Barak valley of Assam is distributed in the Ganga-Brahmaputra-Meghna river systems of India, Bangladesh, and Nepal (Choudhury 1997; Moreno 2003; Nowak 1999; 2003; Kasuya and Haque 1972; Shrestha 1989; Reeves et al. 1993). It was once commonly observed in the major tributaries of Assam. However, the siltation of these rivers and hunting led to a serious decrease in its population. We recorded 3 individuals in Biswanath Ghat.

Earlier records from Assam: Brahmaputra and Barak river basin (Biswas and Boruah 2000; Singha 2000; Wakid 2005; 2006; Biswas et al. 1997; Mazumder et al. 2014; Mohan et al. 1997). 


\section{Notes on the population of near threatened species}

Black-necked stork, Ephippiorhynchus asiaticus

Black-necked stork is a widely distributed species (Rahmani 1989), ranging from Pakistan, across the Indian subcontinent to China, Indonesia, and New Guinea to Australia. In India their population has been declining and is declared almost extinct in Thailand (Lekagul and Round 1991). It is found in the extreme south of Laos (Thewlis et al. 1998; Duckworth et al. 1999). Previously it was common in Cambodia but the population has drastically decreased (BirdLife International 2001). The total population of this species in South East Asia is estimated to be 1,000 individuals (Wetland International 2003). New Guinea is another refuge for the species, which supports over 1,000 individuals (BirdLife International 2004). 187 Black-necked Stork was recorded from 59 sites in 13 states across India (Maheswaram et al. 2004). The population size is decreasing in Assam. Earlier this species was known to be common in many areas of Biswanath but in the present study, only 3 individuals were observed in Rowmari-beel, one in Kodomoni and Ogota each.

Earlier records from Assam: Dibru-saikhowa National Park (Choudhury 2006), Orang National Park (Chakdar et al. 2019), Kaziranga National Park (Baruah and Sharma 1999; Raj et al. 1989), Nameri National Park (Das and Deori 2010), Jhanjimuk-Kokilamukh, Jorhat (Mahanta et al. 2019).

\section{Black-headed ibis, Threskiornis melanocephalus}

Black-headed Ibis is native to Asia (Hancock et al. 2001; Ali and Ripley 2007; BirdLife International 2020). They migrate to Japan, Korea, and Mongolia. Only a few nesting colonies are recorded in India: Gujarat (Tiwari and Rahmani 1998), Rajasthan (Chaudhury and Koli 2018), and Kerala (Balakrishnan and Thomas 2004; Narayanan et al 2006). Nine individuals of this species were seen in agricultural fields near Rowmari beel.

Earlier records from Assam: Kaziranga National Park (Sarma and Barua 1999), Jhanjimuk-Kokilamukh, Jorhat (Mahanta et al. 2019).

\section{Spot-billed pelican, Pelecanus philippensis}

Spot-billed pelican is the most threatened species among the seven species of Pelicans. The total number of this species is about 2,500-5,000 individuals in South Asia, 3,000-5,000 individuals in South East Asia and <25 individuals in Sumatra (BirdLife International 2001, Wetlands International 2006). During the waterfowl census of 1990, a total of 2236 individuals were recorded from Assam (Das 1991). We recorded 11 individuals of this species in Rowmari beel.

Earlier records from Assam: Orang National Park (Chakdar et al. 2019), Kaziranga National Park (Sarma and Barua 1999), Dibru-Saikhowa National Park (Choudhury 2006), Jhanjimuk-Kokilamukh, Jorhat (Mahanta et al. 2019).

\section{Oriental darter, Anhinga melanogaster}

It is distributed in Southeast Asia including India. Till the year, 2000 it was a lower risk species, but in 2004 it was declared as a near-threatened species. Day by day their population is decreasing due to habitat loss and the construction of dams. The total estimated population of this species is about 22,000 mature individuals (BirdLife International 2020). We recorded 91 individuals in Rowmari beel, Kodomoni beel, Ogota beel, Dhondi beel, and Kuwri tank.

Earlier records from Assam: Orang National Park (Chakdar et al. 2019), Dibru-Saikhowa National Park (Choudhury 2006), Kaziranga National Park (Sarma and Barua 1999), Nameri National Park (Das and Deori 2010), Jhanjimuk-Kokilamukh, Jorhat (Mahanta et al. 2019).

\section{Ferruginous pochard, Aythya nyroca}

Ferruginous pochard breeding range is mainly in central and eastern Europe and South-western Asia. The total global population of this species is about 49,000 individuals and the species is considered to be globally threatened. The main four largest population is found in the West Mediterranean and North Africa (Hagemeijer and Blair 1997; Krivenko et al. 1994; Scott and Rose 1997; Snow and Perrins 1998). We recorded 88 individuals in Rowmari Beel, 16 individuals in Kodomoni beel, 4 individuals in Ogota beel, and 90 individuals in Dhondi beel.

Earlier records from Assam: Orang National Park (Chakdar et al. 2019), Kaziranga National Park (Sarma and Barua 1999), Dibru-Saikhowa National Park (Choudhury 2006), Jhanjimuk-Kokilamukh, Jorhat (Mahanta et al. 2019).

Grey-headed fish eagle, Haliaeetus icthyaetus

A total of $10,000-1,00,000$ individuals is present globally and is gradually decreasing (BirdLife International 2020). The distribution of this species ranges from Nepal to Southeast Asia including Northeast India (Ferguson-Lees and Christie 2001). The main threats to this species include deforestation, the use of pesticides, and other anthropogenic activities (BirdLife International 2001). We recorded two individuals in Rowmari-beel, a single individual in Kodomoni-beel on Bombax ceiba with a single nest. One more was recorded in Dhondi-beel.

Earlier records from Assam: Orang National Park (Chakdar et al. 2019), Kaziranga National Park (Sarma and Barua 1999), Dibru-Saikhowa National Park (Choudhury 2006), Jhanjimuk-Kokilamukh, Jorhat (Mahanta et al.2019).

\section{River lapwing, Vanellus duvaucelli}

According to Birdlife International (2020), the total population of River lapwing is about 10000-19999. The distribution of this species ranges from Northern and Southern India, Nepal, Bhutan, Bangladesh, and Myanmar to Indochina (Ali 2002). The population size is gradually decreasing pushing it to a near-threatened species (BirdLife International, 2001). Hunting, deforestation, and the collection of its eggs from the wild are the main threats to this species. We recorded two individuals in Gerekijan wetland and two individuals in Biswanath Ghat. 
Earlier records from Assam: Orang National Park (Chakdar et al. 2019), Nameri National Park (Das and Deori 2010), Dibru-Saikhowa National Park (Choudhury 2006), Kaziranga National Park (Sarma and Barua 1999), Jhanjimuk-Kokilamukh, Jorhat (Mahanta et al. 2019).

Northern lapwing, Vanellus vanellus

It is a migratory species distributed in South and North Africa, Northern India, Pakistan, China, North America, and Canada (Godfrey and Earl 1986). We recorded 21 individuals in Rowmari Beel, a single individual in Kawri Beel, and about 40-45 individuals in Botiamari.

Earlier records from Assam: Orang National Park (Chakdar et al. 2019), Nameri National Park (Das and Deori 2010), Dibru-Saikhowa National Park (Choudhury 2006), Kaziranga National Park (Sarma and Barua 1999), Jhanjimuk-Kokilamukh, Jorhat (Mahanta et al. 2019).

Great thick-knee, Esacus recurvirostris

It is distributed throughout southern Asia from India, Pakistan, Sri Lanka, and Bangladesh to Southeast Asia. We recorded a single individual in Umatumoni, Biswanath Ghat on the bank of the river Brahmaputra.

Earlier records from Assam: Orang National Park (Chakdar et al. 2019), Kaziranga National Park (Sarma and Barua 1999), Dibru-Saikhowa National Park (Choudhury 2006), Jhanjimuk-Kokilamukh, Jorhat (Mahanta et al. 2019).

\section{River tern, Sterna aurantia}

It is distributed throughout southern Asia from India, Pakistan, Sri Lanka, and Bangladesh to Southeast Asia. It is a resident breeder of Iran and the Indian Subcontinent and generally prefers river banks. We recorded eight individuals in Rowmari beel.

Earlier records from Assam: Orang National Park (Chakdar et al. 2019), Dibru-Saikhowa National Park (Choudhury 2006), Kaziranga National Park (Sarma and Baruah 1999), Nameri National Park (Das and Deori 2010), Jhanjimuk-Kokilamukh, Jorhat (Mahanta et al. 2019).

Knife fish, Chitala chitala

It is mainly found in Indian rivers and wetlands such as Indus, Ganges, Brahmaputra, and Mahanadi, etc. (Froese and Pauly 2019). This is a common fish we recorded in Rowmari-beel, Kari-beel, Shildubi, Kodomoni-beel, Kawri-beel, Kalidubi, Dhondi-beel, Pavoi greens, Kuwori pukhuri, and Kalyani temple tank.

Earlier records from Assam: Sone beel (Ngasepam et al. 2015), Kulsi River (Islam et al. 2013), an unspecified locality within Assam (Goswami et al. 2012; Goswami and Zade 2015; Baro et al. 2014; Das and Biswas 2009; Goswami et al. 2007; Talwar and Jhingran 1991; Sarmah et al. 2004).

\section{Gangetica alia, Ailia coila}

Also known as Gangetic Ailia, it is a species of catfish native to India, Bangladesh, Nepal, and Pakistan (Froese and Pauly 2019). We recorded it from Kalidubi, Dhondibeel, and Kalyani temple tank.

Earlier records from Assam: Sone beel (Ngasepam et al. 2015), Kulsi River (Islam et al. 2013), an unspecified locality within Assam (Goswami et al. 2012; Goswami and Zade 2015; Baro et al. 2014; Das and Biswas 2009; Goswami et al. 2007; Talwar and Jhingran 1991; Sarmah et al. 2004).

Butter catfish, Ompok bimaculatus

It is widely distributed in Southeast Asia (Ferraris and Carl 2007; Froese and Pauly 2019). Earlier it was common in Assam but now their population is decreasing gradually. We recorded from 4 sites, namely Rowmari-beel, Ogotabeel, Dhondi-beel, and Biswanath Ghat.

Earlier records from Assam: Sone beel (Ngasepam et al. 2015), Kulsi River (Islam et al. 2013), an unspecified locality within Assam (Goswami et al. 2012; Goswami and Zade 2015; Baro et al. 2014; Das and Biswas 2009; Goswami et al. 2007; Talwar and Jhingran 1991; Sarmah et al. 2004).

During our study, we also observed three other species (White-winged duck, Cairina scutulata, EN; Falcated duck, Anas falcata, NT and Blyth's kingfisher, Alcedo hercules, NT), but as we could not gather any record shots and are based on single observations, hence are not enumerated in the checklist. Kakati and Tamuli (2019) have erroneously reported Cyclemys gemeli as Cyclemys dentata from Nagshankar Temple tank.

Table 3. List of flowering plants recorded in wetlands of Biswanath, Assam, India

\begin{tabular}{llcc}
\hline Family & Taxon & IUCN Threat status & Collection number \\
\hline Acanthaceae & Hygrophila phlomoides Nees & NE & DB 012 \\
Acanthaceae & Hygrophila polysperma (Roxb.) T.Anderson & NE & DB 013 \\
Alismataceae & Butomopsis latifolia (D.Don) Kunth & LC & DB 014 \\
Alismataceae & Sagittaria guayanensis subsp. lappula (D.Don) Bogin & NE & DB 015 \\
Amaranthaceae & Alternanthera sessilis (L.) R.Br. ex DC. & LC & DB 016 \\
Amaranthaceae & Celosia argentea L. & NE & NE 017 \\
Amaryllidaceae & Crinum amoenum Ker Gawl. ex. Roxb. & NE & DB 018 \\
Aponogetonaceae & Aponogeton undulatus Roxb. & NE & DB 019 \\
Asparagaceae & Dracaena terniflora Roxb. & NE & DB 020 \\
Balsaminaceae & Impatiens glandulifera Royle & NE & DB 021 \\
Boraginaceae & Rotula aquatica Lour. & LC & DB 022 \\
Campanulaceae & Lobelia zeylanica L. & DB 024 \\
\hline
\end{tabular}




\begin{tabular}{|c|c|c|c|}
\hline Campanulaceae & Lobelia chinensis Lour. & $\mathrm{NE}$ & DB 023 \\
\hline Commelinaceae & Commelina diffusa Burm.f. & $\mathrm{LC}$ & DB 026 \\
\hline Commelinaceae & Commelina benghalensis L. & NE & DB 025 \\
\hline Commelinaceae & Floscopa scandens Lour. & NE & DB 027 \\
\hline Commelinaceae & Murdannia keisak (Hassk.) Hand.-Mazz. & NE & DB 028 \\
\hline Commelinaceae & Murdannia nudiflora (L.) Brenan & NE & DB 029 \\
\hline Convolvulaceae & Ipomoea aquatica Forssk. & $\mathrm{LC}$ & DB 031 \\
\hline Convolvulaceae & Merremia hirta (L.) Merr & NE & DB 030 \\
\hline Cyperaceae & Schoenoplectiella mucronata (L.) J.Jung \& H.K.Choi & $\mathrm{NE}$ & DB 032 \\
\hline Eriocaulaceae & Eriocaulon brownianum Mart. & $\mathrm{LC}$ & DB 033 \\
\hline Eriocaulaceae & Eriocaulon nepalense J.D.Prescott ex Bong. & NE & DB 034 \\
\hline Hydrocharitaceae & Nechamandra alternifolia (Roxb. ex Wight) Thwaites & $\mathrm{LC}$ & DB 037 \\
\hline Hydrocharitaceae & Ottelia alismoides (L.) Pers. & $\mathrm{LC}$ & DB 038 \\
\hline Hydrocharitaceae & Blyxa aubertii Rich. & NE & DB 035 \\
\hline Hydrocharitaceae & Hydrilla verticillata (L.f.) Royle & NE & DB 036 \\
\hline Hydroleaceae & Hydrolea zeylanica (L.) Vahl & NE & DB 039 \\
\hline Lamiaceae & Pogostemon auricularius (L.) Hassk. & NE & DB 040 \\
\hline Lamiaceae & Pogostemon stellatus (Lour.) Kuntze & NE & DB 041 \\
\hline Lauraceae & Litsea khasyana Meisn. & NE & DB 042 \\
\hline Lecythidaceae & Barringtonia acutangula (L.) Gaertn. & NE & DB 043 \\
\hline Lentibulariaceae & Utricularia aurea Lour. & NE & DB 044 \\
\hline Lentibulariaceae & Utricularia bifida $\mathrm{L}$. & $\mathrm{NE}$ & DB 045 \\
\hline Linderniaceae & Bonnaya antipoda (L.) Druce & NE & DB 046 \\
\hline Linderniaceae & Bonnaya ciliata (Colsm.) Spreng. & NE & DB 047 \\
\hline Linderniaceae & Bonnaya ruellioides (Colsm.) Spreng. & NE & DB 048 \\
\hline Linderniaceae & Lindernia hyssopioides (L.) Haines & NE & DB 049 \\
\hline Linderniaceae & Lindernia rotundifolia (L.) Alston & NE & DB 050 \\
\hline Linderniaceae & Torenia bicolor Dalzell & NE & DB 051 \\
\hline Linderniaceae & Torenia crustacea (L.) Cham. \& Schltdl. & NE & DB 052 \\
\hline Linderniaceae & Vandellia anagallis (Burm.f.) T.Yamaz. & NE & DB 053 \\
\hline Linderniaceae & Vandellia viscosa (Hornem.) Merr. & NE & DB 054 \\
\hline Lythraceae & Ammannia baccifera $\mathrm{L}$. & $\mathrm{LC}$ & DB 055 \\
\hline Lythraceae & Trapa natans var. bispinosa (Roxb.) Makino & $\mathrm{LC}$ & DB 058 \\
\hline Lythraceae & Lagerstroemia speciosa (L.) Pers. & $\mathrm{NE}$ & DB 056 \\
\hline Lythraceae & Rotala rotundifolia (Buch.-Ham. ex Roxb.) Koehne & NE & DB 057 \\
\hline Malvaceae & Hibiscus fragrans Roxb. & NE & DB 059 \\
\hline Menyanthaceae & Nymphoides hydrophylla (Lour.) Kuntze & NE & DB 060 \\
\hline Menyanthaceae & Nymphoides indica (L.) Kuntze & NE & DB 061 \\
\hline Nelumbonaceae & Nelumbo nucifera Gaertn. & NE & DB 062 \\
\hline Nelumbonaceae & Euryale ferox Salisb. & NE & DB 063 \\
\hline Nelumbonaceae & Nymphaea nouchali Burm.f. & NE & DB 064 \\
\hline Onagraceae & Ludwigia adscendens (L.) H.Hara & NE & DB 065 \\
\hline Onagraceae & Ludwigia octovalvis (Jacq.) P.H.Raven & $\mathrm{NE}$ & DB 066 \\
\hline Onagraceae & Ludwigia perennis L. & NE & DB 067 \\
\hline Phyllanthaceae & Phyllanthus assamicus Müll.Arg. & NE & DB 068 \\
\hline Phyllanthaceae & Phyllanthus reticulatus Poir. & NE & DB 069 \\
\hline Plantaginaceae & Dopatrium junceum (Roxb.) Buch.-Ham. ex Benth. & $\mathrm{LC}$ & DB 070 \\
\hline Plantaginaceae & Limnophila chinensis (Osbeck) Merr. & $\mathrm{NE}$ & DB 071 \\
\hline Plantaginaceae & Limnophila sessiliflora (Vahl) Blume & $\mathrm{NE}$ & DB 072 \\
\hline Plantaginaceae & Mecardonia procumbens (Mill.) Small & NE & DB 073 \\
\hline Poaceae & Hygroryza aristata (Retz.) Nees ex Wight \& Arn. & NE & DB 074 \\
\hline Poaceae & Hymenachne amplexicaulis (Rudge) Nees & $\mathrm{NE}$ & DB 075 \\
\hline Polygonaceae & Persicaria strigosa (R.Br.) Nakai & $\mathrm{LC}$ & DB 077 \\
\hline Polygonaceae & Persicaria posumbu (Buch.-Ham. ex D.Don) H.Gross & NE & DB 076 \\
\hline Polygonaceae & Rumex dentatus $\mathrm{L}$. & NE & DB 078 \\
\hline Pontederiaceae & Pontederia hastata $\mathrm{L}$. & NE & DB 079 \\
\hline Pontederiaceae & Pontederia vaginalis Burm.f. & NE & DB 080 \\
\hline Potamogetonaceae & Potamogeton nodosus Poir. & NE & DB 081 \\
\hline Primulaceae & Ardisia icara Wall. ex DC. & $\mathrm{NE}$ & DB 082 \\
\hline Ranunculaceae & Ranunculus sceleratus L. & $\mathrm{NE}$ & DB 083 \\
\hline Rosaceae & Rosa sericea Lindl. & NE & DB 084 \\
\hline Rubiaceae & Dentella repens (L.) J.R.Forst. \& G.Forst. & $\mathrm{LC}$ & DB 085 \\
\hline Rubiaceae & Oldenlandia corymbosa $\mathrm{L}$. & NE & DB 086 \\
\hline Sphenocleaceae & Sphenoclea zeylanica Gaertn. & NE & DB 087 \\
\hline Verbenaceae & Phyla nodiflora (L.) Greene & $\mathrm{LC}$ & DB 088 \\
\hline Xyridaceae & Xyris indica $\mathrm{L}$. & NE & DB 089 \\
\hline Zingiberaceae & Alpinia nigra (Gaertn.) Burtt & NE & DB 090 \\
\hline
\end{tabular}


Table 4. List of birds found in wetlands of Biswanath, Assam, India.

\begin{tabular}{|c|c|c|c|c|c|}
\hline Family & English name/Vernacular name & Scientific name & $\begin{array}{l}\text { Residential } \\
\text { status }\end{array}$ & $\begin{array}{l}\text { Threat } \\
\text { status }\end{array}$ & Abundance (Location) \\
\hline Anatidae & Fulvous whistling duck/Bor sorali & Dendrocygna bicolor (Vieillot, 1748) & $\mathrm{r}$ & LC & $\mathrm{O}(1 \mathrm{a}, 3 \mathrm{a}, 4 \mathrm{a})$ \\
\hline Anatidae & Common Shelduck/Boga Sakoi sokuwa & Tadorna tadorna (Linnaeus, 1758) & $\mathrm{w}$ & $\mathrm{LC}$ & $S(1 b)$ \\
\hline Anatidae & Eurasian Wigeon/Kheri hah & Anas penelope (Linnaeus, 1758) & $\mathrm{W}$ & $\mathrm{LC}$ & S (1a) \\
\hline Anatidae & Northern Shoveler/Khontiya Hah & Anas clypeata (Linnaeus, 1758) & $\mathrm{W}$ & $\mathrm{LC}$ & $S(1 a)$ \\
\hline Anatidae & Indian Spot-billed Duck/Futuki hah & Anas poecilorhyncha (Forster, 1781) & $\mathrm{R}$ & $\mathrm{LC}$ & $\mathrm{O}(1 \mathrm{a}, 2 \mathrm{~b}, 3 \mathrm{a}, 3 \mathrm{c}, 4 \mathrm{a})$ \\
\hline Anatidae & Gargeny/Kajolbulia hah & Anas querquedula (Linnaeus, 1758) & W & $\mathrm{LC}$ & $O(1 a, 3 a, 3 b, 4 b, 8 c)$ \\
\hline Anatidae & Mallard/Amrolia Hah & Anas platyrhynchos (Linnaeus, 1758) & $\mathrm{rW}$ & $\mathrm{LC}$ & $\mathrm{U}(1 \mathrm{a}, 2 \mathrm{~b}, 3 \mathrm{a}, 3 \mathrm{c}, 4 \mathrm{a}, 2 \mathrm{c})$ \\
\hline Anatidae & Tufted Duck/Tikoni hah & Aythya fuligula (Linnaeus, 1758) & $\mathrm{W}$ & $\mathrm{LC}$ & S (1a) \\
\hline Anatidae & Common Pochard/Godhakoli Hah & Aythya ferina (Linnaeus, 1758) & W & VU & S (1a) \\
\hline Anatidae & Northern Pintail/Junga Neji hah & Anas acuta (Linnaeus, 1758) & W & $\mathrm{LC}$ & $\mathrm{U}(1 \mathrm{a}, 2 \mathrm{~b}, 4 \mathrm{~b})$ \\
\hline Anatidae & Ruddy Shelduck/Sakoi-Sokuwa & Tadorna ferruginea (Pallas, 1764) & RW & $\mathrm{LC}$ & $\mathrm{O}(1 \mathrm{a}, 1 \mathrm{~b}, 2 \mathrm{~b}, 2 \mathrm{c}, 3 \mathrm{a}, 3 \mathrm{c}, 4 \mathrm{a}, 4 \mathrm{~b}, 5 \mathrm{c}, 6 \mathrm{c}, 8 \mathrm{c}, 9 \mathrm{c})$ \\
\hline Anatidae & Ferruginous pochard/Borkali Hah & Aythya nyroca (Guldenstadt, 1770) & w & NT & $\mathrm{U}(1 \mathrm{a}, 3 \mathrm{a}, 4 \mathrm{a}, 4 \mathrm{~b})$ \\
\hline Anatidae & Gray leg Goose/Deu-raj hah & Anser anser (Linnaeus, 1758) & $\mathrm{W}$ & $\mathrm{LC}$ & $\mathrm{S}(1 \mathrm{a}, 3 \mathrm{a}, 4 \mathrm{a}, 4 \mathrm{~b})$ \\
\hline Anatidae & Bar-headed Goose/Dhritraj & Anser indicus (Latham, 1790) & rw & $\mathrm{LC}$ & $\mathrm{U}(1 \mathrm{a}, 3 \mathrm{a}, 4 \mathrm{a}, 4 \mathrm{~b}, 6 \mathrm{c}, 8 \mathrm{c}, 9 \mathrm{c})$ \\
\hline Anatidae & Cotton pygmy-goose/Kiki hah & Nettapus coromandalianus (Gmelin, 1789) & $\mathrm{r}$ & $\mathrm{LC}$ & $\mathrm{S}(1 \mathrm{a}, 3 \mathrm{a}, 4 \mathrm{a}, 4 \mathrm{~b}, 5 \mathrm{a})$ \\
\hline Anatidae & Lesser whistling duck/Sorali hah & Dendrocygna javanica (Horsfield, 1821) & $\mathrm{R}$ & $\mathrm{LC}$ & $\begin{array}{l}C(1 a, 3 a, 3 b, 3 c, 4 a, 4 b, 5 a, 5 b, 6 c, 7 a, 7 b, 8 a \\
8 c, 9 a, 9 b, 9 c)\end{array}$ \\
\hline Anatidae & Red crested pochard/Ronga-muri Hah & Netta rufina (Pallas, 1773) & $\mathrm{w}$ & $\mathrm{LC}$ & $\mathrm{S}(1 \mathrm{a}, 3 \mathrm{c})$ \\
\hline Anatidae & Gadwall/Mugi Hah & Anas strepera (Linnaeus, 1758) & $\mathrm{W}$ & $\mathrm{LC}$ & $\mathrm{O}(1 \mathrm{a}, 3 \mathrm{c}, 4 \mathrm{~b})$ \\
\hline Anatidae & Common Teal/Ghila hah & Anas crecca (Linnaeus, 1758) & $\mathrm{W}$ & $\mathrm{LC}$ & $\mathrm{O}(1 \mathrm{a}, 1 \mathrm{~b}, 3 \mathrm{c}, 3 \mathrm{~b}, 4 \mathrm{a}, 4 \mathrm{~b}, 4 \mathrm{c}, 5 \mathrm{a})$ \\
\hline Podicipedidae & Great crested grebe/Bor Dubi & Podiceps cristatus (Linnaeus, 1758) & rw & $\mathrm{LC}$ & $S(1 a, 5 c)$ \\
\hline Podicipedidae & Little Grebe/Pani dubi & Tachybaptus ruficollis (Pallas, 1764) & $\mathrm{R}$ & $\mathrm{LC}$ & $\mathrm{U}(1 \mathrm{a}, 1 \mathrm{~b}, 3 \mathrm{~b}, 4 \mathrm{a}, 4 \mathrm{~b}, 5 \mathrm{a}, 6 \mathrm{c})$ \\
\hline Ciconiidae & Lesser Adjutant Stork/Bortukula & Leptoptilos javanicus (Horsfield, 1821) & $\mathrm{r}$ & VU & $\mathrm{O}(1 \mathrm{a}, 1 \mathrm{c}, 3 \mathrm{a}, 3 \mathrm{~b}, 3 \mathrm{c}, 4 \mathrm{a}, 5 \mathrm{~b}, 5 \mathrm{c}, 6 \mathrm{~b}, 6 \mathrm{c}, 8 \mathrm{a}, 9 \mathrm{a})$ \\
\hline Ciconiidae & Greater adjutant stork/Hargila & Leptoptilos dubius (Gmelin, 1789) & $\mathrm{r}$ & EN & $\mathrm{S}(1 \mathrm{a}, 1 \mathrm{c})$ \\
\hline Ciconiidae & Black stork/Kalsor & Ciconia nigra (Linnaeus, 1758) & $\mathrm{w}$ & $\mathrm{LC}$ & $S(1 a)$ \\
\hline Ciconiidae & Asian Openbill Stork/Samuk vonga & Anastomus oscitans (Boddaert, 1783) & $\mathrm{R}$ & $\mathrm{LC}$ & $\begin{array}{l}\mathrm{C}(1 \mathrm{a}, 1 \mathrm{~b}, 1 \mathrm{c}, 2 \mathrm{a}, 2 \mathrm{~b}, 2 \mathrm{c}, 3 \mathrm{a}, 3 \mathrm{~b}, 3 \mathrm{c}, 4 \mathrm{a}, 4 \mathrm{~b}, 4 \mathrm{c}, 5 \mathrm{a}, \\
5 \mathrm{~b}, 5 \mathrm{c}, 6 \mathrm{a}, 6 \mathrm{~b}, 6 \mathrm{c}, 7 \mathrm{a}, 7 \mathrm{~b}, 8 \mathrm{a}, 8 \mathrm{~b}, 8 \mathrm{c}, 9 \mathrm{a}, 9 \mathrm{~b}, 9 \mathrm{c})\end{array}$ \\
\hline Ciconiidae & Woolly-necked Stork/Konuwa & Ciconia episcopus (Boddaert, 1783) & $\mathrm{R}$ & VU & $\mathrm{O}(1 \mathrm{a}, 3 \mathrm{a}, 8 \mathrm{c}, 9 \mathrm{a})$ \\
\hline Ciconiidae & Black-necked Stork/Telia sareng & Ephippiorhynchus asiaticus (Latham, 1790) & $\mathrm{r}$ & NT & $\mathrm{S}(1 \mathrm{a}, 3 \mathrm{a}, 4 \mathrm{a})$ \\
\hline Threskiornithidae & Black-headed ibis/Kola akuhi bog & Threskiornis melanocephalus (Latham, 1790) & $\mathrm{R}$ & NT & $S(1 a)$ \\
\hline Threskiornithidae & Glossy ibis/Itaguriya akuhi bog & Plegadis falcinellus (Linnaeus, 1766) & RW & $\mathrm{LC}$ & $S(1 a, 4 b)$ \\
\hline Recurvirostridae & Black-winged stilt/Dighol thengia soha & Himantopus himantopus (Linnaeus, 1758) & RW & $\mathrm{LC}$ & $\mathrm{S}(1 \mathrm{a})$ \\
\hline
\end{tabular}




\begin{tabular}{|c|c|c|c|c|c|}
\hline Ardeidae & Black-crowned night heron/Wak sorai & Nycticorax nycticorax (Linnaeus, 1758 ) & $\mathrm{R}$ & LC & $\mathrm{U}(1 \mathrm{a}, 5 \mathrm{a})$ \\
\hline Ardeidae & Grey Heron/Halkheda & Ardea cinerea (Linnaeus, 1758) & RW & $\mathrm{LC}$ & $\mathrm{O}(1 \mathrm{a}, 2 \mathrm{c}, 3 \mathrm{a}, 4 \mathrm{a}, 4 \mathrm{~b}, 5 \mathrm{~b}, 7 \mathrm{~b})$ \\
\hline Ardeidae & Purple Heron/Azan & Ardea purpurea (Linnaeus, 1766) & $\mathrm{R}$ & $\mathrm{LC}$ & $O(1 \mathrm{a}, 3 \mathrm{a}, 4 \mathrm{a}, 4 \mathrm{~b}, 5 \mathrm{~b})$ \\
\hline Ardeidae & Intermediate Egret/Maju bog & Mesophoyx intermedia (Wagler, 1827) & $\mathrm{R}$ & $\mathrm{LC}$ & $\begin{array}{l}\text { C }(1 \mathrm{a}, 1 \mathrm{c}, 3 \mathrm{a}, 3 \mathrm{~b}, 3 \mathrm{c}, 4 \mathrm{a}, 4 \mathrm{~b}, 5 \mathrm{a}, 5 \mathrm{~b}, 7 \mathrm{~b}, 8 \mathrm{a}, 8 \mathrm{~b}, \\
8 \mathrm{c}, 9 \mathrm{a}, 9 \mathrm{~b}, 9 \mathrm{c})\end{array}$ \\
\hline Ardeidae & Great Egret/Bor bog & casmerodius albus (Linnaeus, 1758) & RW & $\mathrm{LC}$ & $\mathrm{O}(1 \mathrm{a}, 1 \mathrm{~b}, 3 \mathrm{a}, 4 \mathrm{a}, 4 \mathrm{~b})$ \\
\hline Ardeidae & Cinnamon Bittern/Itaguriya sorai & Ixobrycgus cinnamomeus (Gmelin, 1789) & $\mathrm{r}$ & $\mathrm{LC}$ & $\mathrm{U}(1 \mathrm{a}, 3 \mathrm{a})$ \\
\hline Ardeidae & Indian Pond Heron/Konamusuri & Ardeola grayii (Sykes, 1832) & $\mathrm{R}$ & $\mathrm{LC}$ & $\begin{array}{l}\text { C (1a, 1b, 1c, 2a, 2b, 2c, 3a, 3b, 3c, 4a, 4b, 4c, 5a, } \\
5 \mathrm{~b}, 5 \mathrm{c}, 6 \mathrm{a}, 6 \mathrm{~b}, 6 \mathrm{c}, 7 \mathrm{a}, 7 \mathrm{~b}, 7 \mathrm{c}, 8 \mathrm{a}, 8 \mathrm{~b}, 8 \mathrm{c}, 9 \mathrm{a}, 9 \mathrm{~b}, \\
9 \mathrm{c})\end{array}$ \\
\hline Ardeidae & Striated Heron/Soru musori & Butorides striatus (Linnaeus, 1758) & $\mathrm{r}$ & LC & $\mathrm{U}(1 \mathrm{a}, 3 \mathrm{a}, 4 \mathrm{a}, 4 \mathrm{~b}, 5 \mathrm{c}, 6 \mathrm{a})$ \\
\hline Ardeidae & Cattle Egret/Gu Bog & Bubulcus ibis (Linnaeus, 1758) & $\mathrm{R}$ & $\mathrm{LC}$ & $\begin{array}{l}\mathrm{C}(1 \mathrm{~b}, 1 \mathrm{c}, 2 \mathrm{~b}, 3 \mathrm{a}, 3 \mathrm{~b}, 3 \mathrm{c}, 4 \mathrm{a}, 4 \mathrm{~b}, 4 \mathrm{c}, 5 \mathrm{a}, 5 \mathrm{~b}, 5 \mathrm{c}, 6 \mathrm{~b} \\
6 \mathrm{c}, 7 \mathrm{a}, 7 \mathrm{~b}, 7 \mathrm{c}, 8 \mathrm{a}, 8 \mathrm{~b}, 8 \mathrm{c}, 9 \mathrm{a}, 9 \mathrm{~b}, 9 \mathrm{c})\end{array}$ \\
\hline Ardeidae & Little Egret/Teteri bog & Egretta garzetta (Linnaeus, 1766) & $\mathrm{R}$ & $\mathrm{LC}$ & $\mathrm{C}(1 \mathrm{a}, 1 \mathrm{~b}, 2 \mathrm{~b}, 3 \mathrm{a}, 4 \mathrm{~b}, 5 \mathrm{c}, 7 \mathrm{~b}, 8 \mathrm{a}, 8 \mathrm{~b}, 8 \mathrm{c}, 9 \mathrm{a}, 9 \mathrm{~b}, 9 \mathrm{c})$ \\
\hline Phalacrocoracidae & Little Cormorant/Pani Kawri & Microcarbo niger (Vieillot, 1817) & $\mathrm{R}$ & $\mathrm{LC}$ & $\begin{array}{l}\mathrm{C}(1 \mathrm{a}, 1 \mathrm{~b}, 1 \mathrm{c}, 2 \mathrm{a}, 2 \mathrm{~b}, 2 \mathrm{c}, 3 \mathrm{a}, 3 \mathrm{~b}, 3 \mathrm{c}, 4 \mathrm{a}, 4 \mathrm{~b}, 4 \mathrm{c}, 5 \mathrm{a}, \\
5 \mathrm{~b}, 5 \mathrm{c}, 6 \mathrm{a}, 6 \mathrm{~b}, 6 \mathrm{c}, 7 \mathrm{a}, 7 \mathrm{~b}, 8 \mathrm{a}, 8 \mathrm{~b}, 8 \mathrm{c}, 9 \mathrm{a}, 9 \mathrm{~b}, 9 \mathrm{c})\end{array}$ \\
\hline Phalacrocoracidae & Indian Cormorant/Koilangi & Phalacrocorax fuscicollis (Stephens, 1826) & $\mathrm{R}$ & $\mathrm{LC}$ & $S(1 a, 4 b, 6 b)$ \\
\hline Phalacrocoracidae & Great Cormorant/Doikola & Phalacrocorax carbo (Linnaeus, 1758) & RW & $\mathrm{LC}$ & $O(1 \mathrm{a}, 3 \mathrm{a}, 4 \mathrm{a}, 4 \mathrm{~b}, 6 \mathrm{~b})$ \\
\hline Pelecanidae & Spot-billed pelican/Vela sorai & Pelecanus philippensis (Gmelin, 1789) & $\mathrm{R}$ & NT & $S(1 a)$ \\
\hline Anhingidae & Oriental darter/Moniyori & Anhinga melanogaster (Pennant, 1769) & $\mathrm{R}$ & NT & $\mathrm{O}(1 \mathrm{a}, 3 \mathrm{a}, 3 \mathrm{~b}, 4 \mathrm{a}, 4 \mathrm{~b}, 6 \mathrm{~b})$ \\
\hline Hirundinidae & Barn swallow/Teltupi & Hirundo rustica (Linnaeus, 1758) & RW & $\mathrm{LC}$ & $\begin{array}{l}\text { C (1a, 1b, 1c, 2a, 2b, 2c, 3a, 3b, 3c, 4a, 4b, 4c, } \\
5 \mathrm{a}, 5 \mathrm{~b}, 5 \mathrm{c}, 6 \mathrm{~b}, 6 \mathrm{c}, 7 \mathrm{a}, 7 \mathrm{~b} 8 \mathrm{~b}, 8 \mathrm{c}, 9 \mathrm{a}, 9 \mathrm{~b}, 9 \mathrm{c})\end{array}$ \\
\hline Accipitridae & Pallas's fish eagle/Bor ukoh & Haliaeetus leucoryphus (Pallas, 1771) & $\mathrm{r}$ & EN & $\mathrm{S}(1 \mathrm{~b})$ \\
\hline Accipitridae & Grey-headed fish eagle/Ukoh & Haliaeetus icthyaetus (Horsfield, 1821) & $\mathrm{r}$ & NT & $\mathrm{U}(1 \mathrm{a}, 3 \mathrm{a}, 4 \mathrm{~b})$ \\
\hline Accipitridae & Osprey/Kuruwa & Pandion haliaetus (Linnaeus, 1758) & rw & $\mathrm{LC}$ & $O(1 \mathrm{a}, 3 \mathrm{a}, 4 \mathrm{a}, 4 \mathrm{~b})$ \\
\hline Charadriidae & River lapwing/Balighura & Vanellus duvaucelli (Lesson, 1826) & $\mathrm{R}$ & NT & $\mathrm{U}(5 \mathrm{c}, 7 \mathrm{~b})$, \\
\hline Charadriidae & Red-wattled lapwing/Hotitiya & Vanellus indicus (Boddaert, 1783) & $\mathrm{R}$ & $\mathrm{LC}$ & $\begin{array}{l}\mathrm{C}(1 \mathrm{a}, 1 \mathrm{~b}, 1 \mathrm{c}, 2 \mathrm{a}, 2 \mathrm{~b}, 2 \mathrm{c}, 3 \mathrm{a}, 3 \mathrm{~b}, 3 \mathrm{c}, 4 \mathrm{a}, 4 \mathrm{~b}, 4 \mathrm{c}, 5 \mathrm{a}, \\
5 \mathrm{~b}, 5 \mathrm{c}, 6 \mathrm{a}, 6 \mathrm{~b}, 6 \mathrm{c}, 7 \mathrm{a}, 7 \mathrm{~b}, 8 \mathrm{a})\end{array}$ \\
\hline Charadriidae & Grey-headed lapwing/Dolghura & Vanellus cinereus (Blyth, 1842) & $\mathrm{w}$ & $\mathrm{LC}$ & $\mathrm{U}(1 \mathrm{a}, 3 \mathrm{a}, 4 \mathrm{a}, 4 \mathrm{~b}, 4 \mathrm{c}, 6 \mathrm{a}, 6 \mathrm{~b}, 7 \mathrm{~b})$ \\
\hline Charadriidae & Northern Lapwing/Silghura & Vanellus vanellus (Linnaeus, 1758) & $\mathrm{w}$ & NT & $\mathrm{S}(1 \mathrm{a}, 4 \mathrm{~b}, 8 \mathrm{c})$ \\
\hline Charadriidae & Little ringed plover/Loriyoli & Charadrius dubius (Scopoli, 1786) & RW & $\mathrm{LC}$ & $O(1 \mathrm{a}, 3 \mathrm{~b}, 5 \mathrm{c}, 7 \mathrm{~b}, 8 \mathrm{c})$ \\
\hline Burhinidae & Great thick-knee/Dangor silkotora & Esacus recurvirostris (Cuvier, 1829) & $\mathrm{r}$ & NT & $S(5 c)$ \\
\hline Burhinidae & Indian thick-knee/Silkotora & Burhinus indicus (Salvadori, 1865) & $\mathrm{R}$ & LC & $\mathrm{S}(1 \mathrm{~b})$ \\
\hline Jacanidae & Bronze-winged jacana/Dolpunga & Metopidius indicus (Latham, 1790) & $\mathrm{R}$ & $\mathrm{LC}$ & $\begin{array}{l}\mathrm{C}(1 \mathrm{a}, 1 \mathrm{~b}, 1 \mathrm{c}, 2 \mathrm{~b}, 2 \mathrm{c}, 3 \mathrm{a}, 3 \mathrm{~b}, 3 \mathrm{c}, 4 \mathrm{a}, 4 \mathrm{~b}, 4 \mathrm{c}, 5 \mathrm{a}, 5 \mathrm{~b}, \\
5 \mathrm{c}, 6 \mathrm{~b}, 6 \mathrm{c}, 7 \mathrm{a}, 7 \mathrm{~b} 8 \mathrm{a}, 8 \mathrm{c}, 9 \mathrm{a})\end{array}$ \\
\hline Jacanidae & Pheasant-tailed jacana/Dolmora & Hydrophasianus chirurgus (Scopoli, 1786) & $\mathrm{R}$ & $\mathrm{LC}$ & $S(1 a, 3 a)$ \\
\hline Rostratulidae & Common snipe/Balituka & Gallinago gallinago (Linnaeus, 1758) & $\mathrm{rW}$ & $\mathrm{LC}$ & $S(1 a, 3 a, 6 a)$ \\
\hline Rostratulidae & Greater painted snipe/Rongsongia bali khusora & Rostratula benghalensis (Linnaeus, 1758) & W & $\mathrm{LC}$ & $S(6 a)$ \\
\hline
\end{tabular}




\begin{tabular}{|c|c|c|c|c|c|}
\hline Scolopacidae & Green Sandpiper/Bali Boguwa & Tringa ochropus (Linnaeus, 1758) & $\mathrm{W}$ & LC & $\mathrm{S}(1 \mathrm{a}, 6 \mathrm{a})$ \\
\hline Scolopacidae & Common Greenshank/Pat thengi & Tringa nebularia (Gunnerus, 1767) & $\mathrm{W}$ & $\mathrm{LC}$ & $\mathrm{U}(1 \mathrm{a}, 3 \mathrm{a}, 4 \mathrm{a}, 4 \mathrm{~b})$ \\
\hline Scolopacidae & Little stint/Chereka sorai & Calidris minuta (Leisler, 1812) & W & $\mathrm{LC}$ & $\mathrm{U}(1 \mathrm{a}, 2 \mathrm{a}, 3 \mathrm{a}, 6 \mathrm{a})$ \\
\hline Scolopacidae & Temminck's stint/Not found & Calidris temminckii (Leisler, 1812) & W & $\mathrm{LC}$ & $\mathrm{U}(2 \mathrm{a}, 6 \mathrm{a})$ \\
\hline Scolopacidae & Common Sandpiper/Bali khusora & Actitis hypoleucos (Linnaeus, 1758) & $\mathrm{sW}$ & $\mathrm{LC}$ & $\mathrm{U}(1 \mathrm{a}, 4 \mathrm{~b})$ \\
\hline Laridae & $\begin{array}{l}\text { Black-headed gull/Kalfut sagor siloni, Ram } \\
\text { paro }\end{array}$ & Chroicocephalus ridibundus (Linnaeus, 1766) & $\mathrm{R}$ & $\mathrm{LC}$ & $S(1 a, 3 a)$ \\
\hline Rallidae & River tern/Gonga-siloni & Sterna aurantia (Gray, 1831) & $\mathrm{R}$ & NT & $S(1 a, 3 a, 4 a, 4 b)$ \\
\hline Rallidae & Water Rail/Dolsora & Rallus aquaticus (Linnaeus, 1758) & rw & LC & $S(1 \mathrm{a}, 4 \mathrm{~b}, 7 \mathrm{~b})$ \\
\hline Rallidae & White-breasted waterhen/Dauk & Amaurornis phoenicurus (Pennant, 1769) & $\mathrm{R}$ & $\mathrm{LC}$ & $\begin{array}{l}\mathrm{C}(1 \mathrm{a}, 1 \mathrm{~b}, 1 \mathrm{c}, 2 \mathrm{a}, 2 \mathrm{~b}, 2 \mathrm{c}, 3 \mathrm{a}, 3 \mathrm{~b}, 3 \mathrm{c}, 4 \mathrm{a}, 4 \mathrm{~b}, 4 \mathrm{c}, 5 \mathrm{a}, \\
5 \mathrm{~b}, 5 \mathrm{c}, 6 \mathrm{~b}, 6 \mathrm{c}, 7 \mathrm{a}, 7 \mathrm{~b}, 8 \mathrm{a}, 8 \mathrm{~b}, 8 \mathrm{c}, 9 \mathrm{a}, 9 \mathrm{~b}, 9 \mathrm{c})\end{array}$ \\
\hline Rallidae & Purple Swamphen/Kam sorai & Porphyrio porphyrio (Linnaeus, 1758) & $\mathrm{R}$ & $\mathrm{LC}$ & $S(4 a)$ \\
\hline Phasianidae & Swamp Francolin/ Hoikoli & Francolinsus gularis (Temminck, 1815) & $\mathrm{r}$ & VU & $\mathrm{S}(1 \mathrm{a}, 6 \mathrm{a})$ \\
\hline Rallidae & Eurasian coot/Nol Dhekor & Fulica atra (Linnaeus, 1758) & RW & $\mathrm{LC}$ & S (1a) \\
\hline Rallidae & Common Moorhen/Desi kura dhekor & Gallinula chloropus (Linnaeus, 1758) & $\mathrm{R}$ & $\mathrm{LC}$ & $\mathrm{O}(1 \mathrm{a}, 1 \mathrm{c})$ \\
\hline Muscicapidae & Black-backed forktail/Ketepa tip & Enicurus immaculatus (Hodgson, 1836) & $\mathrm{r}$ & $\mathrm{LC}$ & $O(1 a, 6 a)$ \\
\hline Motacillidae & White wagtail/Boga Balimahi & Motacilla alba (Linnaeus, 1758) & $\mathrm{rW}$ & $\mathrm{LC}$ & $\begin{array}{l}\mathrm{C}(1 \mathrm{a}, 1 \mathrm{~b}, 1 \mathrm{c}, 2 \mathrm{~b}, 2 \mathrm{c}, 3 \mathrm{a}, 3 \mathrm{~b}, 3 \mathrm{c}, 4 \mathrm{a}, 4 \mathrm{~b}, 4 \mathrm{c}, 5 \mathrm{a}, 5 \mathrm{~b}, \\
5 \mathrm{c}, 6 \mathrm{~b}, 6 \mathrm{c}, 7 \mathrm{a}, 7 \mathrm{~b}, 8 \mathrm{a}, 8 \mathrm{~b}, 8 \mathrm{c}, 9 \mathrm{a}, 9 \mathrm{~b}, 9 \mathrm{c})\end{array}$ \\
\hline Motacillidae & Cristine wagtail/Balimahi & Motacilla citreola (Pallas, 1776) & $\mathrm{rW}$ & $\mathrm{LC}$ & $\begin{array}{l}\mathrm{C}(1 \mathrm{a}, 1 \mathrm{~b}, 1 \mathrm{c}, 2 \mathrm{~b}, 2 \mathrm{c}, 3 \mathrm{a}, 3 \mathrm{~b}, 3 \mathrm{c}, 4 \mathrm{a}, 4 \mathrm{~b}, 4 \mathrm{c}, 5 \mathrm{a}, 5 \mathrm{c}, \\
6 \mathrm{~b}, 7 \mathrm{~b}, 8 \mathrm{c}, 4 \mathrm{c})\end{array}$ \\
\hline Alcedinidae & $\begin{array}{l}\text { White-breasted Kingfisher/Boga bukuwa } \\
\text { masruka }\end{array}$ & Halcyon smyrnensis (Linnaeus, 1758) & $\mathrm{R}$ & $\mathrm{LC}$ & $\begin{array}{l}\mathrm{C}(1 \mathrm{a}, 1 \mathrm{~b}, 1 \mathrm{c}, 2 \mathrm{a}, 2 \mathrm{~b}, 2 \mathrm{c}, 3 \mathrm{a}, 3 \mathrm{~b}, 3 \mathrm{c}, 4 \mathrm{a}, 4 \mathrm{~b}, 4 \mathrm{c}, 5 \mathrm{a}, \\
5 \mathrm{~b}, 5 \mathrm{c}, 6 \mathrm{a}, 6 \mathrm{~b}, 6 \mathrm{c}, 7 \mathrm{a}, 7 \mathrm{~b}, 8 \mathrm{a}, 8 \mathrm{~b}, 8 \mathrm{c}, 9 \mathrm{a}, 9 \mathrm{~b} .9 \mathrm{c})\end{array}$ \\
\hline Alcedinidae & Blue-eared kingfisher/Nila masruka & Alcedo meninting (Horsfield, 1821) & $\mathrm{r}$ & $\mathrm{LC}$ & $S(1 b)$ \\
\hline Alcedinidae & Lesser Pied Kingfisher/Pokhora masruka & Ceryle rudis (Linnaeus, 1758) & $\mathrm{R}$ & $\mathrm{LC}$ & $\mathrm{U}(1 \mathrm{a}, 3 \mathrm{a}, 3 \mathrm{~b}, 8 \mathrm{c})$ \\
\hline Alcedinidae & Stork-billed Kingfisher/Bor thutia masruka & Pelargopsis capensis (Linnaeus, 1766) & $\mathrm{R}$ & $\mathrm{LC}$ & $\mathrm{U}(1 \mathrm{a}, 2 \mathrm{a}, 2 \mathrm{~b}, 3 \mathrm{a}, 4 \mathrm{a}, 6 \mathrm{a}, 7 \mathrm{~b})$ \\
\hline Alcedinidae & Ruddy Kingfisher/Rongosuwa Masruka & Halcyon coromanda (Latham, 1790) & $\mathrm{r}$ & $\mathrm{LC}$ & $\mathrm{U}(6 \mathrm{a})$ \\
\hline Alcedinidae & Common Kingfisher/Masruka & Acedo atthis (Linnaeus, 1758) & $\mathrm{R}$ & $\mathrm{LC}$ & $\mathrm{O}(1 \mathrm{a}, 2 \mathrm{~b}, 3 \mathrm{a}, 3 \mathrm{~b}, 3 \mathrm{c}, 4 \mathrm{a}, 4 \mathrm{~b}, 6 \mathrm{a}, 7 \mathrm{~b})$ \\
\hline
\end{tabular}


Table 5. List of fishes found in wetlands of Biswanath, Assam, India

\begin{tabular}{|c|c|c|c|c|}
\hline Family & English name/Vernacular name & Scientific name & $\begin{array}{l}\text { Threat } \\
\text { status }\end{array}$ & Occurrence \\
\hline Cyprinidae & Kuria labeo/Kurhi & Labeo gonius (Hamilton, 1822) & $\mathrm{LC}$ & $\mathrm{C}(1 \mathrm{a}, 1 \mathrm{c}, 2 \mathrm{~b}, 2 \mathrm{c}, 3 \mathrm{a}, 3 \mathrm{~b}, 3 \mathrm{c}, 4 \mathrm{a}, 4 \mathrm{~b}, 5 \mathrm{a}, 5 \mathrm{~b}, 5 \mathrm{c}, 6 \mathrm{~b}, 6 \mathrm{c}, 7 \mathrm{a}, 7 \mathrm{~b})$ \\
\hline Cyprinidae & Bata/Kuriha & Labeo bata (Hamilton, 1822) & $\mathrm{LC}$ & $\mathrm{C}(1 \mathrm{a}, 2 \mathrm{~b}, 3 \mathrm{~b}, 4 \mathrm{~b}, 5 \mathrm{c})$ \\
\hline Cyprinidae & Black rohu/Mali & Labeo calbasu (Hamilton, 1822) & $\mathrm{LC}$ & $O(1 \mathrm{a}, 1 \mathrm{c}, 2 \mathrm{~b}, 3 \mathrm{a}, 3 \mathrm{~b}, 3 \mathrm{c}, 4 \mathrm{a}, 4 \mathrm{~b}, 4 \mathrm{c}, 5 \mathrm{a}, 5 \mathrm{~b}, 6 \mathrm{c}, 7 \mathrm{~b})$ \\
\hline Cyprinidae & Rohu/Row & Labeo rohita (Hamilton, 1822) & $\mathrm{LC}$ & C (1a, 1b, 1c, 2a, 2b, 2c, 3a, 3b, 3c, 4a, 4b, 5a, 5b, 6b, 6c, 7a, 7b, 8c, 9b) \\
\hline Cyprinidae & Catla/Bahu & Catla catla (Hamilton, 1822) & $\mathrm{LC}$ & $\mathrm{C}(1 \mathrm{a}, 1 \mathrm{~b}, 1 \mathrm{c}, 2 \mathrm{~b}, 2 \mathrm{c}, 3 \mathrm{a}, 3 \mathrm{~b}, 3 \mathrm{c}, 4 \mathrm{a}, 4 \mathrm{~b}, 5 \mathrm{a}, 5 \mathrm{~b}, 6 \mathrm{~b}, 6 \mathrm{c}, 7 \mathrm{a}, 7 \mathrm{~b}, 8 \mathrm{c}, 9 \mathrm{~b})$ \\
\hline Cyprinidae & Spotfin swamp barb/Puthi & Puntius sophore (Hamilton, 1822) & $\mathrm{LC}$ & $\mathrm{C}(1 \mathrm{a}, 1 \mathrm{c}, 2 \mathrm{~b}, 2 \mathrm{c}, 3 \mathrm{a}, 3 \mathrm{~b}, 3 \mathrm{c}, 4 \mathrm{a}, 4 \mathrm{~b}, 5 \mathrm{a}, 5 \mathrm{~b}, 6 \mathrm{~b}, 6 \mathrm{c}, 7 \mathrm{a}, 7 \mathrm{~b}, 8 \mathrm{c}, 9 \mathrm{~b})$ \\
\hline Cyprinidae & Ticto barb/Chenaputhi & Puntius tico (Hamilton, 1822) & $\mathrm{LC}$ & $O(1 a, 1 c, 3 a, 3 b, 4 a, 4 b .5 b, 7 b)$ \\
\hline Cyprinidae & Swamp barb/Sela puthi & Puntius chola (Hamilton, 1822) & $\mathrm{LC}$ & $\mathrm{C}(1 \mathrm{a}, 1 \mathrm{c}, 2 \mathrm{~b}, 2 \mathrm{c}, 3 \mathrm{a}, 3 \mathrm{~b}, 3 \mathrm{c}, 4 \mathrm{a}, 4 \mathrm{~b}, 5 \mathrm{a}, 5 \mathrm{~b}, 5 \mathrm{c}, 6 \mathrm{~b}, 6 \mathrm{c}, 7 \mathrm{a}, 7 \mathrm{~b})$ \\
\hline Cyprinidae & Java barb/Java Puthi & Puntius javanica (Bleeker, 1850) & $\mathrm{LC}$ & $\mathrm{O}(1 \mathrm{c}, 2 \mathrm{c}, 3 \mathrm{a}, 3 \mathrm{~b}, 4 \mathrm{a}, 5 \mathrm{a}, 5 \mathrm{~b}, 7 \mathrm{a})$ \\
\hline Cyprinidae & Olive barb/Cheni puthi & Puntius sarana (Hamilton, 1822) & $\mathrm{LC}$ & $\mathrm{C}(1 \mathrm{a}, 1 \mathrm{c}, 2 \mathrm{a}, 2 \mathrm{~b}, 2 \mathrm{c}, 3 \mathrm{a}, 3 \mathrm{~b}, 3 \mathrm{c}, 4 \mathrm{a}, 4 \mathrm{~b}, 5 \mathrm{a}, 5 \mathrm{~b}, 6 \mathrm{~b}, 6 \mathrm{c}, 7 \mathrm{a}, 7 \mathrm{~b}, 8 \mathrm{c}, 9 \mathrm{~b})$ \\
\hline Cyprinidae & Mrigal carp/Mirika & Cirrhinus mrigala (Bloch, 1795) & $\mathrm{LC}$ & $\mathrm{C}(1 \mathrm{a}, 1 \mathrm{c}, 2 \mathrm{a}, 2 \mathrm{~b}, 2 \mathrm{c}, 3 \mathrm{a}, 3 \mathrm{~b}, 3 \mathrm{c}, 4 \mathrm{a}, 4 \mathrm{~b}, 5 \mathrm{a}, 5 \mathrm{~b}, 6 \mathrm{~b}, 6 \mathrm{c}, 7 \mathrm{a}, 7 \mathrm{~b}, 8 \mathrm{c}, 9 \mathrm{~b})$ \\
\hline Cyprinidae & Indian flying barb/Darikana & Esomus danricus (Hamilton, 1822) & $\mathrm{LC}$ & $\mathrm{C}(1 \mathrm{a}, 1 \mathrm{~b}, 1 \mathrm{c}, 2 \mathrm{a}, 2 \mathrm{~b}, 2 \mathrm{c}, 3 \mathrm{a}, 3 \mathrm{~b}, 3 \mathrm{c}, 4 \mathrm{a}, 4 \mathrm{~b}, 4 \mathrm{c}, 5 \mathrm{a}, 5 \mathrm{~b}, 5 \mathrm{c}, 6 \mathrm{a}, 6 \mathrm{~b}, 6 \mathrm{c}, 8 \mathrm{c}, 9 \mathrm{~b})$ \\
\hline Cyprinidae & Cabdio morar/Boliora & Aspidoparia morar (Hamilton, 1822) & $\mathrm{LC}$ & 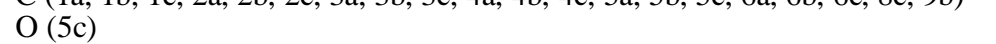 \\
\hline Cyprinidae & Reba carp/Lachim bhangun & Cirrhinus reba (Hamilton, 1822) & $\mathrm{LC}$ & $O(2 a, 5 b, 6 b, 6 c)$ \\
\hline Cyprinidae & Common carp/Common Carp & Cyprinus carpio (Linnaeus, 1758) & VU & $\mathrm{C}(2 \mathrm{a}, 5 \mathrm{~b}, 5 \mathrm{c}, 6 \mathrm{~b}, 6 \mathrm{c})$ \\
\hline Cyprinidae & Large razorbelly minnow/Chela & Salmostoma bacaila (Hamilton, 1822) & $\mathrm{LC}$ & C $(2 a, 5 b, 6 b, 6 c)$ \\
\hline Cyprinidae & Queen loach/Botuk & Botia dario (Hamilton, 1822) & $\mathrm{LC}$ & $\mathrm{C}(1 \mathrm{a}, 1 \mathrm{c}, 2 \mathrm{~b}, 2 \mathrm{c}, 3 \mathrm{a}, 3 \mathrm{~b}, 3 \mathrm{c}, 4 \mathrm{a}, 4 \mathrm{~b}, 5 \mathrm{a}, 5 \mathrm{~b}, 6 \mathrm{~b}, 6 \mathrm{c}, 7 \mathrm{a}, 7 \mathrm{~b}$ \\
\hline Cyprinidae & Mola carplet/Moa & Amblypharyngodon mola (Hamilton, 1822) & $\mathrm{LC}$ & $\mathrm{C}(1 \mathrm{a}, 1 \mathrm{c}, 2 \mathrm{~b}, 2 \mathrm{c}, 3 \mathrm{a}, 3 \mathrm{~b}, 3 \mathrm{c}, 4 \mathrm{a}, 4 \mathrm{~b}, 5 \mathrm{a}, 5 \mathrm{~b}, 5 \mathrm{c}, 6 \mathrm{~b}, 6 \mathrm{c}, 7 \mathrm{a}, 7 \mathrm{~b})$ \\
\hline Anabantidae & Climbing Perch/kawoi & Anabas testudineus (Bloch, 1792) & $\mathrm{LC}$ & $\mathrm{C}(1 \mathrm{a}, 1 \mathrm{~b}, 1 \mathrm{c}, 2 \mathrm{a}, 2 \mathrm{~b}, 2 \mathrm{c}, 3 \mathrm{a}, 3 \mathrm{~b}, 3 \mathrm{c}, 4 \mathrm{a}, 4 \mathrm{~b}, 4 \mathrm{c}, 5 \mathrm{a}, 5 \mathrm{~b}, 5 \mathrm{c}, 6 \mathrm{a}, 6 \mathrm{~b}, 6 \mathrm{c}, 7 \mathrm{a}, 7 \mathrm{~b}, 8 \mathrm{c}, 9 \mathrm{~b})$ \\
\hline Channidae & Snakehead species/Goroi & Channa punctata (Bloch, 1793) & $\mathrm{LC}$ & $\mathrm{C}(1 \mathrm{a}, 1 \mathrm{~b}, 1 \mathrm{c}, 2 \mathrm{a}, 2 \mathrm{~b}, 2 \mathrm{c}, 3 \mathrm{a}, 3 \mathrm{~b}, 3 \mathrm{c}, 4 \mathrm{a}, 4 \mathrm{~b}, 4 \mathrm{c}, 5 \mathrm{a}, 5 \mathrm{~b}, 5 \mathrm{c}, 6 \mathrm{a}, 6 \mathrm{~b}, 6 \mathrm{c}, 7 \mathrm{a}, 7 \mathrm{~b}, 8 \mathrm{c}, 9 \mathrm{~b})$ \\
\hline Channidae & Great snakehead/Sal & Channa marulius (Hamilton, 1822) & $\mathrm{LC}$ & $O(1 a, 2 b, 3 a, 3 b, 4 a, 4 b, 6 a)$ \\
\hline Channidae & Striped snakehead/Sol & Channa striatus (Bloch, 1793) & $\mathrm{LC}$ & $O(1 a, 2 b, 2 c, 3 a, 3 b, 3 c, 4 a, 4 b, 4 c, 5 a, 5 b, 5 c, 6 a, 6 c, 7 a)$ \\
\hline Bagridae & Tengara catfish/Dangor Singora & Mystus tengara (Hamilton, 1822) & $\mathrm{LC}$ & $\mathrm{C}(1 \mathrm{a}, 1 \mathrm{~b}, 1 \mathrm{c}, 2 \mathrm{~b}, 2 \mathrm{c}, 3 \mathrm{a}, 3 \mathrm{~b}, 3 \mathrm{c}, 4 \mathrm{a}, 4 \mathrm{~b}, 4 \mathrm{c}, 5 \mathrm{a}, 5 \mathrm{~b}, 6 \mathrm{~b}, 6 \mathrm{c}, 7 \mathrm{a}, 7 \mathrm{~b})$ \\
\hline Bagridae & Gangetic mystus/Ganga singora & Mystus cavasius (Hamilton, 1822) & $\mathrm{LC}$ & $\mathrm{C}(1 \mathrm{a}, 1 \mathrm{~b}, 1 \mathrm{c}, 2 \mathrm{a}, 2 \mathrm{~b}, 2 \mathrm{c}, 3 \mathrm{a}, 3 \mathrm{~b}, 3 \mathrm{c}, 4 \mathrm{a}, 4 \mathrm{~b}, 4 \mathrm{c}, 5 \mathrm{a}, 5 \mathrm{~b}, 5 \mathrm{c}, 6 \mathrm{a}, 6 \mathrm{~b}, 6 \mathrm{c}, 7 \mathrm{a}, 7 \mathrm{~b})$ \\
\hline Bagridae & Striped dwarf catfish/Soru Singora & Mystus vittatus (Bloch, 1794) & $\mathrm{LC}$ & $\mathrm{C}(1 \mathrm{a}, 1 \mathrm{~b}, 1 \mathrm{c}, 2 \mathrm{a}, 2 \mathrm{~b}, 2 \mathrm{c}, 3 \mathrm{a}, 3 \mathrm{~b}, 3 \mathrm{c}, 4 \mathrm{a}, 4 \mathrm{~b}, 4 \mathrm{c}, 5 \mathrm{a}, 5 \mathrm{~b}, 5 \mathrm{c}, 6 \mathrm{a}, 6 \mathrm{~b}, 6 \mathrm{c}, 7 \mathrm{a}, 7 \mathrm{~b}, 8 \mathrm{c}, 9 \mathrm{~b})$ \\
\hline Siluridae & Helicopter catfish or wallago catfish/Borali & Wallago attu (Bloch \& Schneider, 1801) & VU & $\mathrm{U}(1 \mathrm{a}, 1 \mathrm{~b}, 1 \mathrm{c}, 2 \mathrm{~b}, 3 \mathrm{a}, 3 \mathrm{~b}, 3 \mathrm{c}, 4 \mathrm{a}, 4 \mathrm{~b}, 4 \mathrm{c}, 5 \mathrm{a}, 5 \mathrm{~b}, 5 \mathrm{c}, 6 \mathrm{c}, 7 \mathrm{a}, 7 \mathrm{~b}, 8 \mathrm{c}, 9 \mathrm{~b})$ \\
\hline Siluridae & Butter catfish/Pabho & Ompok bimaculatus (Bloch, 1794)) & NT & $\mathrm{U}(1 \mathrm{a}, 3 \mathrm{~b}, 4 \mathrm{~b}, 5 \mathrm{c})$ \\
\hline Pangasiidae & Basa/Bosa & Pagasius bocourti (Sauvage, 1880) & LC & $\mathrm{O}(1 \mathrm{a}, 5 \mathrm{c})$ \\
\hline Heteropneustidae & Fossil cat/Singi & Heteropneustes fossolis (Bloch, 1794) & $\mathrm{LC}$ & $\mathrm{C}(1 \mathrm{a}, 1 \mathrm{~b}, 1 \mathrm{c}, 2 \mathrm{a}, 2 \mathrm{~b}, 2 \mathrm{c}, 3 \mathrm{a}, 3 \mathrm{~b}, 3 \mathrm{c}, 4 \mathrm{a}, 4 \mathrm{~b}, 4 \mathrm{c}, 5 \mathrm{a}, 5 \mathrm{~b}, 5 \mathrm{c}, 6 \mathrm{a}, 6 \mathrm{~b}, 6 \mathrm{c})$ \\
\hline Notopteridae & Indian Knifefish/Chital & Chitala chitala (Hamilton, 1822) & NT & $\mathrm{O}(1 \mathrm{a}, 1 \mathrm{~b}, 2 \mathrm{~b}, 2 \mathrm{c}, 3 \mathrm{a}, 3 \mathrm{c}, 4 \mathrm{a}, 4 \mathrm{~b}, 5 \mathrm{~b}, 6 \mathrm{c}, 8 \mathrm{c}, 9 \mathrm{~b})$ \\
\hline Notopteridae & Bronze featherback/Kandhuli & Notopterus notopterus (Pallas, 1769) & $\mathrm{LC}$ & $\mathrm{C}(1 \mathrm{a}, 1 \mathrm{~b}, 2 \mathrm{a}, 2 \mathrm{~b}, 2 \mathrm{c}, 3 \mathrm{a}, 3 \mathrm{~b}, 3 \mathrm{c}, 4 \mathrm{a}, 4 \mathrm{~b}, 4 \mathrm{c}, 5 \mathrm{a}, 5 \mathrm{~b}, 6 \mathrm{~b}, 6 \mathrm{c}, 7 \mathrm{a}, 7 \mathrm{~b})$ \\
\hline Clupeidae & Indian river shad/Koroti & Gudusia chapra (Hamilton, 1822) & $\mathrm{LC}$ & $O(1 \mathrm{a}, 1 \mathrm{c}, 3 \mathrm{a}, 3 \mathrm{~b}, 4 \mathrm{a}, 4 \mathrm{~b} .5 \mathrm{~b}, 7 \mathrm{~b}, 9 \mathrm{c})$ \\
\hline Synbranchidae & Swamp eels/Kuchia & Monopterus cuchia (Lacepede, 1800) & $\mathrm{LC}$ & $\mathrm{C}(1 \mathrm{a}, 2 \mathrm{~b}, 2 \mathrm{c}, 3 \mathrm{a}, 3 \mathrm{~b}, 3 \mathrm{c}, 4 \mathrm{a}, 4 \mathrm{~b}, 4 \mathrm{c}, 5 \mathrm{a}, 5 \mathrm{~b}, 5 \mathrm{c}, 6 \mathrm{a}, 6 \mathrm{c}, 7 \mathrm{a}, 7 \mathrm{~b})$ \\
\hline Synbranchidae & Barred spiny eel/Tora & Macrognathus puncalus (Hamilton, 1822) & $\mathrm{LC}$ & $\mathrm{C}(1 \mathrm{a}, 1 \mathrm{~b}, 1 \mathrm{c}, 2 \mathrm{a}, 2 \mathrm{~b}, 2 \mathrm{c}, 3 \mathrm{a}, 3 \mathrm{~b}, 3 \mathrm{c}, 4 \mathrm{a}, 4 \mathrm{~b}, 4 \mathrm{c}, 5 \mathrm{a}, 5 \mathrm{~b}, 5 \mathrm{c}, 6 \mathrm{a}, 6 \mathrm{~b}, 6 \mathrm{c}, 7 \mathrm{a}, 7 \mathrm{~b})$ \\
\hline Mastacembelidae & One-stripe spiny eel/Tura & Macrognathus aral (Bloch \& Schneider, 1801) & $\mathrm{LC}$ & $\mathrm{C}(1 \mathrm{a}, 1 \mathrm{~b}, 1 \mathrm{c}, 2 \mathrm{a}, 2 \mathrm{~b}, 2 \mathrm{c}, 3 \mathrm{a}, 3 \mathrm{~b}, 3 \mathrm{c}, 4 \mathrm{a}, 4 \mathrm{~b}, 5 \mathrm{a}, 5 \mathrm{~b}, 6 \mathrm{a}, 6 \mathrm{~b}, 6 \mathrm{c}, 7 \mathrm{a}, 7 \mathrm{~b})$ \\
\hline Mastacembelidae & Zig-zag eel/Bami & Mastacembelus armatus (Lacepede, 1800) & $\mathrm{LC}$ & $\mathrm{O}(1 \mathrm{a}, 1 \mathrm{~b}, 2 \mathrm{~b}, 3 \mathrm{a}, 3 \mathrm{~b}, 4 \mathrm{a}, 4 \mathrm{~b}, 4 \mathrm{c}, 6 \mathrm{a}, 7 \mathrm{~b})$ \\
\hline Nandidae & Gangetic lea & Nandus nandus (Hamilton, 1822) & $\mathrm{LC}$ & $\mathrm{C}(1 \mathrm{a}, 1 \mathrm{~b}, 1 \mathrm{c}, 2 \mathrm{a}, 2 \mathrm{~b}, 2 \mathrm{c}, 3 \mathrm{a}, 3 \mathrm{~b}, 3 \mathrm{c}, 4 \mathrm{a}, 4 \mathrm{~b}, 5 \mathrm{a}, 5 \mathrm{~b}, 6 \mathrm{a}, 6 \mathrm{~b}, 6 \mathrm{c}, 7 \mathrm{a}, 7 \mathrm{~b}, 8 \mathrm{c}, 9 \mathrm{~b})$ \\
\hline Botiidae & Guntea loach/Botia & Lepidocephalus guntea (Hamilton, 1822) & $\mathrm{LC}$ & $\mathrm{C}(1 \mathrm{a}, 1 \mathrm{~b}, 1 \mathrm{c}, 2 \mathrm{a}, 2 \mathrm{~b}, 2 \mathrm{c}, 3 \mathrm{a}, 3 \mathrm{~b}, 3 \mathrm{c}, 4 \mathrm{a}, 4 \mathrm{~b}, 5 \mathrm{a}, 5 \mathrm{~b}, 6 \mathrm{a}, 6 \mathrm{~b}, 6 \mathrm{c}, 7 \mathrm{a}, 7 \mathrm{~b})$ \\
\hline Schilbeidae & Gangetic alia/Kajuli & Ailia coila (Hamilton, 1822) & NT & $\mathrm{U}(4 \mathrm{a}, 4 \mathrm{~b}, 5 \mathrm{~b})$ \\
\hline Clariidae & Walking catfish/Magur & Clarias batrachus (Linnaeus, 1758) & $\mathrm{LC}$ & $\mathrm{O}(1 \mathrm{a}, 1 \mathrm{~b}, 1 \mathrm{c}, 2 \mathrm{~b}, 2 \mathrm{c}, 3 \mathrm{a}, 3 \mathrm{~b}, 3 \mathrm{c}$ \\
\hline Ambassidae & Chanda beculis/Chanda & Parambassis baculis (Hamilton, 1822) & $\mathrm{LC}$ & $\mathrm{C}(1 \mathrm{a}, 1 \mathrm{~b}, 1 \mathrm{c}, 2 \mathrm{~b}, 2 \mathrm{c}, 3 \mathrm{a}, 3 \mathrm{~b}, 3 \mathrm{c}, 4 \mathrm{a}, 4 \mathrm{~b}, 5 \mathrm{a}, 5 \mathrm{~b}, 6 \mathrm{a}, 6 \mathrm{~b}, 6 \mathrm{c}, 7 \mathrm{a}, 7 \mathrm{~b}, 8 \mathrm{c}, 9 \mathrm{~b})$ \\
\hline Ambassidae & Elongate glassy perchlet/Chanda & Chanda nama (Hamilton, 1822) & $\mathrm{LC}$ & $\mathrm{C}(1 \mathrm{a}, 1 \mathrm{~b}, 1 \mathrm{c}, 2 \mathrm{~b}, 2 \mathrm{c}, 3 \mathrm{a}, 3 \mathrm{~b}, 3 \mathrm{c}, 4 \mathrm{a}, 4 \mathrm{~b}, 5 \mathrm{a}, 5 \mathrm{~b}, 6 \mathrm{a}, 6 \mathrm{~b}, 6 \mathrm{c}, 7 \mathrm{a}, 7 \mathrm{~b}, 8 \mathrm{c}, 9 \mathrm{~b})$ \\
\hline Badidae & Blue badis/Nabat & Badis badis (Hamilton, 1822) & $\mathrm{LC}$ & $\mathrm{C}(2 \mathrm{~b}, 4 \mathrm{a}, 4 \mathrm{~b}, 7 \mathrm{~b})$ \\
\hline Gobiidae & Tank Gobi/Patitmutura & Glossogobius giuris (Hamilton, 1822) & $\mathrm{LC}$ & $\mathrm{U}(1 \mathrm{a}, 2 \mathrm{~b}, 2 \mathrm{c}, 3 \mathrm{a}, 3 \mathrm{~b}, 4 \mathrm{a}, 4 \mathrm{~b}$ \\
\hline Osphronemidae & Striped gourami/Kholiana & Colisa fasciatus (Bloch \& Schneider, 1801) & $\mathrm{LC}$ & $\mathrm{O}(1 \mathrm{a}, 1 \mathrm{~b}, 1 \mathrm{c}, 2 \mathrm{a}, 2 \mathrm{~b}, 2 \mathrm{c}, 3 \mathrm{a}, 3 \mathrm{~b}, 3 \mathrm{c}, 4 \mathrm{a}, 4 \mathrm{~b}, 5 \mathrm{a}, 5 \mathrm{~b}, 6 \mathrm{a}, 6 \mathrm{~b}, 6 \mathrm{c}, 7 \mathrm{a}, 7 \mathrm{~b}, 8 \mathrm{c}, 9 \mathrm{~b})$ \\
\hline Tetraodontidae & Ocellated pufferfish/Gongatup & Tetraodon cutcutia (Hamilton, 1822) & $\mathrm{LC}$ & $O(1 a, 2 b, 3 a, 3 b, 4 a, 4 b)$ \\
\hline Belonidae & Freshwater garfish/Kokila & Xenentodon cancila (Hamilton, 1822) & $\mathrm{LC}$ & C (1a, 1c, 2b, 2c, 3a, 3b, 3c, 4a, 4b, 4c, 5a, 5b,5c, 6b, 6c, 7a, 7b) \\
\hline
\end{tabular}


Table 6. List of amphibians found in wetlands of Biswanath, Assam, India

\begin{tabular}{|c|c|c|c|c|}
\hline Family & English name/Vernacular name & Scientific name & $\begin{array}{l}\text { Threat } \\
\text { status }\end{array}$ & Occurrence \\
\hline Dicroglossidae & Indian bullfrog/Bamun vekula & Hoplobatrachus tigerinus (Daudin, 1803) & LC & $\mathrm{O}(1 \mathrm{a}, 3 \mathrm{a}, 4 \mathrm{~b}, 4 \mathrm{c}, 6 \mathrm{a}, 8 \mathrm{c})$ \\
\hline Dicroglossidae & Pierre's cricket frog & Zakerana pierrei (Dubois, 1975) & $\mathrm{LC}$ & $S(1 a, 6 a)$ \\
\hline Dicroglossidae & Terai cricket frog & Zakerana teraiensis (Dubois, 1984) & $\mathrm{LC}$ & $O(1 \mathrm{a}, 6 \mathrm{a}, 5 \mathrm{c}, 6 \mathrm{~b}, 8 \mathrm{c}, 9 \mathrm{~b})$ \\
\hline Dicroglossidae & Long-legged cricket frog & Zakerana syhadrensis (Annandale, 1919) & $\mathrm{LC}$ & $\begin{array}{l}\text { C (1a, 1b, 1c, 2a, 2b, 2c, 3a, 3b, 3c, 4a, 4b, 4c, 5a, 5b, 5c, 6a, 6b 6c, 7a, 7b, } \\
7 \mathrm{c}, 8 \mathrm{a}, 8 \mathrm{~b}, 8 \mathrm{c}, 9 \mathrm{~b})\end{array}$ \\
\hline Dicroglossidae & Indian skipper frog/Pani beng & Euphlyctis cyanophlyctis (Schneider, 1799) & $\mathrm{LC}$ & $\mathrm{C}(1 \mathrm{a}, 1 \mathrm{~b}, 1 \mathrm{c}, 2 \mathrm{a}, 2 \mathrm{~b}, 2 \mathrm{c}, 3 \mathrm{a}, 3 \mathrm{~b}, 3 \mathrm{c}, 4 \mathrm{a}, 4 \mathrm{~b}, 4 \mathrm{c}, 5 \mathrm{a}, 5 \mathrm{~b}, 5 \mathrm{c}, 6 \mathrm{a}, 6 \mathrm{~b}, 6 \mathrm{c}, 7 \mathrm{a}, 7 \mathrm{~b})$ \\
\hline Bufonidae & Common Indian Toad/Suk vekuli & Duttaphrynus melanostictus (Schneider, 1799) & $\mathrm{LC}$ & $\begin{array}{l}\mathrm{C}(1 \mathrm{a}, 1 \mathrm{~b}, 1 \mathrm{c}, 2 \mathrm{a}, 2 \mathrm{~b}, 2 \mathrm{c}, 3 \mathrm{a}, 3 \mathrm{~b}, 3 \mathrm{c}, 4 \mathrm{a}, 4 \mathrm{~b}, 4 \mathrm{c}, 5 \mathrm{a}, 5 \mathrm{~b}, 5 \mathrm{c}, 6 \mathrm{a}, 6 \mathrm{~b} 6 \mathrm{c}, 7 \mathrm{a}, 7 \mathrm{~b}, \\
7 \mathrm{c}, 8 \mathrm{a}, 8 \mathrm{~b}, 8 \mathrm{c}, 9 \mathrm{a}, 9 \mathrm{~b}, 9 \mathrm{c})\end{array}$ \\
\hline Rhacophoridae & Four lined tree frog/Pat beng & Polypedates leucomystax (Gravenhorst, 1829) & $\mathrm{LC}$ & $\mathrm{S}(1 \mathrm{a}, 3 \mathrm{a}, 5 \mathrm{c}, 6 \mathrm{a}, 7 \mathrm{a})$ \\
\hline
\end{tabular}

Table 7. List of reptiles found in wetlands of Biswanath, Assam, India

\begin{tabular}{llll}
\hline Family & English name/Vernacular name & Scientific name & Threat \\
status
\end{tabular}


Table 8. List of mammals found in wetlands of Biswanath, Assam, India

\begin{tabular}{|c|c|c|c|c|}
\hline Family & $\begin{array}{l}\text { English name/Vernacular } \\
\text { name }\end{array}$ & Scientific name & $\begin{array}{l}\text { Threat } \\
\text { status } \\
\end{array}$ & Occurrence \\
\hline Mustelidae & Smooth-coated otter/Uud & Lutrogale perspicillata (Hilaire, 1826) & VU & $S(1 a, 5 c)$ \\
\hline Platanistidae & Ganges River Dolphin/Sihu & Platanista gangetica (Lebeck, 1801); (Roxburgh, 1801) & EN & $S(5 c)$ \\
\hline
\end{tabular}

In conclusion, Biswanath District of Assam, India hosts some of the ideal habitats for safeguarding the present biodiversity, the state holds. The reason behind is because the south boundary of the district is a part of the Kaziranga National Park, which forms a vast network of floodplains (grasslands and moist deciduous forests) hosting a vast range of habitats, and similarly the north of the district is covered by the foothills of Eastern Himalaya which spans across a long stretch of semi-evergreen forests. Apart from that, the major tributaries (Borgang and Buroi) of the river Brahmaputra have silted a vast expanse of lands in its boundaries which are converted into grasslands and wetlands, providing ample habitat for several dependent species. Moreover, the habitat heterogeneity, as well as the climate adds to the reasons. But the increasing human pressure has impacted severely the survival of the left habitats and in turn to the species. Agricultural expansion, illegal settlements, filling of lowlands, overfishing, conversion into fisheries, exploitation of the other resources, are the most important threats to the remaining wetlands.

\section{ACKNOWLEDGEMENTS}

The authors are thankful to Chittaranjan Kakati, Chandan Mech, Shivjyoti Ingti, Debarun Talukdar, Parixit Kafley, Suman Kondha, Arup Borah, Pranjal Baruah, Hrishikesh Mahanta, Sabir Ahmed, and Munna Gorh for their help in data collection and identification. We also extend our sincere thanks to different communities of Biswanath, Assam for providing necessary help throughout the study.

\section{REFERENCES}

Ahmed MF, Das A, Dutta SK. 2009. Amphibians and Reptiles of Northeast India, A Photographic Guide. Aaranyak, Guwahati.

Ahmed MF, Das A. 2009. Tortoises and Freshwater Turtles of Kaziranga National Park, Assam-Diversity, Distribution, Conservation Status. In: Vasudevan K. (eds) ENVIS Bulletin: Wildlife and Protected Areas. Dehradun, India.

Akbar M, Mushtaq-Ul-Hassan M, Muhammad-U-Nisa Z. 2006. Distribution of freshwater turtles in Punjab, Pakistan. Caspian J Environ Sci 4: 142-146.

Ali S, Ripley SD. 2007. Handbook of the birds of India and Pakistan. Oxford University Press, New Delhi.

Ali S. 2002. The book of Indian birds. Oxford University Press, New Delhi.

Balakrishnan M, Thomas SK. 2004. Conserving the breeding habitat of the near-threatened Oriental White ibis Threskiornis melanocephalus. Current Sci 87: 1190-1192.
Barker DG, Barker TM. 2008. The Distribution of the Burmese Python, Python molurus bivittatus. Bull Chicago Herpetol Soc 43: 33-38.

Barker DG, Barker TM. 2010. The Distribution of the Burmese Python, Python bivittatus in China. Bull Chicago Herpetol Soc 45: 86-88.

Barman PD. 2011. Conservation initiative for greater adjutant stork in Assam, India. Aaranyak, Assam.

Barman R, Saikia P, Singha HJ, Talukdar BK, Bhattacharya PC. 1995. Study on the population trend of waterbirds at Deepor beel Wildlife Sanctuary, Assam. Pavo 33: 25-40.

Baro DC, Sharma S, Baishya AR. 2014. Status of ornamental fish diversity of Sonkosh River, Bodoland Territorial Council, Assam, India. Sci Vis 14: 28-38.

Barooah C, Mahanta PK. 2006. Aquatic angiosperms of Biswanath Chariali, Assam. Indian J For 29: 307-318.

Barua M, Sharma P. 1999. Birds of Kaziranga National Park, India. Forktail 15: 47-60.

Bassi N, Kumar MD. 2012. Addressing the civic challenges: perspective on institutional change for sustainable urban water management in India. Environ Urban Asia 3: 165-183.

Basumatary R, Sharma DK. 2013. The turtle fauna of Kaziranga National Park, Assam, India with notes on natural history and conservation status. Herpetol Notes 6: 59-72.

Bibby CJ, Hill DA, Burgess N, Mustoe S. 2000. Bird census techniques. Academic Press, London.

BirdLife International. 2020. IUCN Red List for birds. Downloaded from http://www.birdlife.org on 29/11/2020.

BirdLife International. 2001. Threatened birds of Asia: the BirdLife International Red Data Book. BirdLife International, Cambridge.

BirdLife International. 2004. Threatened birds of world. BirdLife International, Cambridge U.K.

BirdLife International. 2013. IUCN Red List for birds. Downloaded from http://www.birdlife.org on 09 June 2013.

Biswas SP, Baruah A, Mohan RSL. 1997. Current status of river dolphin (Platanista gangetica) in the river Brahmaputra. Intl $\mathrm{J}$ Ecol and Environ Sci 23: 357-361.

Biswas SP, Boruah S. 2000. Ecology of river dolphin (Platanista gangetica) in the Upper Brahmaputra. Hydrobiology 430: 97-111.

Borah D, Das B, Tangjang S, Das AP, Khapugin AA. 2021. Assessment of woody species diversity and composition along a disturbance gradient in Behali Reserve Forest of Biswanath District, Assam, India. Ecol Quest 32: 1-25.

Borah D, Kafley P, Tangjang S, Das AP. 2018. Population structure and conservation of endangered Citrus indica Yu.Tanaka (Rutaceae) in Behali Reserve Forest of Assam, India. Pleione 12: 181-186.

Borah D, Tanaka N, Averyanov L, Taram M, Roy DK. 2020a. Rediscovery of Tupistra stoliczkana (Asparagaceae) in northeastern India and the identity of T.ashihoi. Phytotaxa 443: 207-210.

Borah D, Tangjang S, Das AP, Upadhaya A, Mipun P. 2020b. Assessment of non-timber forest products (NTFPs) in Behali Reserve Forest, Assam, Northeast India. Ethnobot Res Appl 19: 43.

Borah D, Tangjang S. 2020c. Behali Reserve Forest of Assam, Northeast India-unique elements of flora, its threats and protection. In: Kunz M. (ed) Role and Functioning of Landscape Parks in the Biosphere Reserves, Torun, Poland.

Borah D, Taram M, Das AP, Tangjang S, Van Do T. 2019a. Aristolochia assamica (Aristolochiaceae), a new species from the East Himalayas. Annales Botanici Fennici 56: 253-257.

Borah D, Taram M, Tangjang S, Upadhyaya A, Tanaka N0. 2020d. Peliosanthes macrophylla var. assamensis (Asparagaceae), a new variety from Behali Reserve Forest in Assam, Northeast India. Blumea 65: 121-125. 
Borah, D, Kafley P, Das AP, Tangjang S, Averynov L. 2019b. Chlorophytum assamicum (Asparagaceae), a new species from Northeast India. Phytotaxa 394: 123-125.

Breuer H, Murphy WC. 2009-2010. "Python molurus bivittatus" Snakes of Taiwan. Retrieved 20 October 2020.

Burnham JW, Wood EM. 2012. Woolly-necked Stork, Ciconia episcopus at Napahai wetland, Yunnan, China. Forktail 28: 158-159.

Chakdar B, Singha H, Choudhury MR. 2019. A bird community of Rajiv Gandhi Orang National Park, Assam. J Asia-Pac Biodiv 12: 498-507.

Champion HG, Seth SK. 1968. A Revised Classification of Forest Types of India. Manager of Publications, New Delhi.

Changkakati HC, Das RK. 1991. Nesting behavior of greater adjutant stork. Indian Forester 117: 892-895.

Chaudhury S, Koli VK. 2018. Population status, habitat preference, and nesting characteristics of black-headed ibis Threskiornis melanocephalus Latham, 1790 in southern Rajasthan, India. J AsiaPac Biod 11: 223-228.

Choudhury NK., Sharma DK, Sengupta S. 1999. Diversity and distribution of Kchuga in Kamrup District, Assam. Tiger Paper 26: 27-29.

Choudhury AU. 1990. Turtles recorded in Dibru-saikhowa wildlife sanctuary, Assam. J Ecol Soc 8: 33-39.

Choudhury AU. 1991. Bird observation from Sibsagar district, Assam, India. Forktail 6: 35-42.

Choudhury AU. 1992. Sighting of the Great White-bellied Heron in Jamjing Reserve forest, Assam. Newslett Birdwatcher 32: 7-8.

Choudhury AU. 1993. Nesting colonies of Greater adjutant storks in Nagaon and Sivsagar district of Assam. Newslett Birdwatchers 33: 47-48.

Choudhury AU. 1997. Checklist of the Mammals of Assam. Gibbon Books, Guwahati.

Choudhury AU. 2000. The Birds of Assam. Gibbon Books and WWFIndia NE Region, Guwahati.

Choudhury AU. 2004. Kaziranga-Wildlife in Assam. Rupa and Co., New Delhi.

Choudhury AU. 2006. Birds of Dibru-Saikhowa National Park and Biosphere Reserve, Assam, India. Indian Birds 2: 95-105.

Choudhury AU. 2013. The mammals of Northeast India. Gibbon Books and The Rhino Foundation for Nature in Northeast India, Guwahati.

Crump ML, Scott NJJ. 1994. Visual encounter surveys. In (eds) Heyer WR, Donnelly MA, McDiarmid RW, Hayek LAC, Foster MS. Measuring and Monitoring Biological Diversity: Standard Methods for Amphibians. Smithsonian Institution Press, USA.

Daniel JC. 2016. The book of Indian reptiles and amphibians. Bombay Natural History Society, Oxford University Press, Mumbai.

Das I, Basu D, Singh S. 2010. Nilssonia hurum (Gray 1830)-Indian Peacock Softshell Turtle. Conservation Biology of Freshwater Turtles and Tortoises. Chelonian Res Monogr 5: 481-486.

Das I, Sengupta S, Praschag P. 2010. Pangshura sylhetensis Jerdon 1870Assam Roofed Turtle. In: Rhodin AGJ, Pritchard PC, van Dijk PP Saumure RA, Buhlmann KA, Iverson JB, Mittermeier RA. (eds) Conservation Biology of Freshwater Turtles and Tortoises: A Compilation Project of the IUCN/SSC Tortoise and Freshwater Turtle Specialist Group. IUCN, Gland.

Das I. 1995. Turtles and Tortoises of India. WWF India and Oxford, Bombay.

Das LC, Mukherjee AK. 1974. List of some important faunal representatives of the Kaziranga national park (flora and fauna). Indian Museum Bulletin, Calcutta

Das JN, Biswas SP. 2009. Current status and diversity of ornamental fishes in the floodplain wetlands of the upper Brahmaputra basin. In: Kosygin L. (ed) Wetlands of North East India: Ecology, Aquatic Bioresources and Conservation. Akansha Publishing House, New Delhi.

Das N, Deori S. 2010. The Birds of Nameri National Park, Assam, India: An annotated checklist. Bird Popul 10: 37-55.

Das RK. 1991. Assam: the main breeding ground of Spot-billed Pelican. Newslett Birdwatchers 31: 12-13.

Das RK. 1995. White-winged Duck Cairina scutulata in Nameri Sanctuary, Assam. Threatened Waterfowl Specialist Group Newslett 8: $17-18$.

Das S, Datta D, Saha N, Hye FB. 2018. Conservation Status of Black Soft Shell Turtle (Nilssonia nigricans) in Bangladesh. J Wildlife Res 6: 12-16.

Datta S. 1997. Freshwater turtles and tortoises of Dhubri District. Zoos' Print 12: 1-4.
Datta S. 2013. A handbook on bird watching. Bonful Publishers, Guwahati.

Deka B, Saikia PK. 2015. Diversity of chelonian species in Orang National Park, Assam, India. J Global BioSci 4: 2150-2167.

Dey SC, Kar D. 1989. Fishermen of Lake Sone in Assam: Their socioeconomic status. Sci Cult 55: 395-398.

Duckworth JW, Salter RE, Khounboline K. 1999. Wildlife in Lao PDR: 1999 status report. Wildlife Conservation Society and Centre for Protected Areas and Watershed Management, Vientiane.

Dutta A. 1998. Records of turtles from Pakhui Wildlife Sanctuary, Arunachal Pradesh, northeast India. J Bombay Nat Hist Soc 95: 121223.

Dutta D, Roy JK., Nath A, Das A, Sengupta S, Dutta A. 2013. Locality Record of Leptobrachium smithi Matsui, Nabhitabhata and Panha, 1999 (Anura: Megophryidae) on the north bank of Brahmaputra river in India. Asian J Conservation Biol 2: 168-171.

eBird 2020. An online database of bird distribution and abundance [web application]. eBird, Cornell Lab of Ornithology, Ithaca, New York. Available: http://www.ebird.org. (Accessed: 29 November 2020).

Efloraofindia. 2007 onwards. Database of Indian Plants-developed by the members of Efloraofindia Google group. Accessed at https://sites.google.com/site/efloraofindia/on [23 June 2020]

Ferguson-Lees J, Christie DA. 2001. Raptors Of The World. Houghton Mifflin, New York.

Ferraris, CJ. 2007. Checklist of catfishes, recent and fossil (Osteichthyes: Siluriformes), and catalog of siluriform primary types. Zootaxa 1418: 1-628.

Fisher T, Hicks N. 2006. A photographic guide to birds of the Philippines. New Holland Publishers, London.

Fritz U, Peter H. 2007. Checklist of Chelonians of the World. Vertebrate Zool 57: 311 .

Froese R, Pauly D. 2019. FishBase, World Wide Web electronic publication. www.fishbase.org, version (12/2019).

Gaston AJ. 1975. Methods for estimating bird populations. J Bombay Natural History Society 72: 271-283.

Ghale TR, Karmacharya, Dikpal K. 2018. A new altitudinal record for Asian woolly neck Ciconia episcopus in South Asia. Birding ASIA 29: 96-97.

Gill F, Wright M. 2006. Birds of world: Recommended English Names. Princeton University Press, Princeton.

Godfrey W. Earl. 1986. The Birds of Canada. National Museum of Natural Sciences, City.

Gogoi PP, Vinoj V, Phukan P. 2020. Role of meteorology and local orography on a flood event in the Lower Subansiri Basin and postflood changes to land use and land cover. Current Sci 118: 778-785.

Goswami C, Zade VS. 2015. Ornamental fish diversity across Brahmaputra Valley of Assam. Intl J Innov Sci Eng Technol 2: $547-$ 549.

Goswami UC, Basistha SK, Bora D, Shyamkumar K, Saikia B, Changsan K. 2012. Fish diversity of North East India, inclusive of the Himalayan and Indo Burma biodiversity hotspots zones: A checklist on their taxonomic status, economic importance, geographical distribution, present status and prevailing threats. Intl $\mathrm{J}$ Biodiv Conserv 4: 592-613.

Goswami UC, Vishwanth W, Jayaram KC, Datta MJS. 2007. Fish Fauna of North East India: Natural and Anthropogenic Hazards on Fish and Fisheries. Narendra Publishing House, Delhi.

Government of Assam. 2011. Census Population 2020 Data. Accessed at https://www.census2011.co.in/on [26 June 2020].

Grewal R, Bhatia G. 2014. A Naturalist's Guide to the Birds of India. Prakash Books India Pvt. Ltd., New Delhi.

Grimmette R, Inskipp C, Inskipp T. 2011. Birds of Indian Subcontinent. Oxford University Press, London.

Hagemeijer WJM, Blair MJ. 1997. The EBCC Atlas of European Breeding Birds, their distribution and abundance. T \& AD Poyser, London.

Hancock J, Kushlan JA, Kahl MP. 1992. Storks, Ibises and Spoonbills of the World. Academic Press, London.

Heyer WR, Donnelly MA, McDiarmid RW, Hayek Lee-Ann C, Foster MS. 1994. Measuring and Monitoring Biological Diversity: Standard Methods for Amphibians. Smithsonian Books, Washington, DC.

Hooker JD. 1872-1897.The Flora of British India. IVII. L. Reeve and Company, London.

WWF, AWB. 1993. World Wide Fund for Nature (WWF) and Asian Wetland Bureau (AWB) Directory of Indian Wetlands. World Wide 
Fund for Nature and Asian Wetland Bureau, New Delhi and Kuala Lumpur.

Inskipp C, Inskipp TP. 1991. A guide to the birds of Nepal, 2nd ed. Croom Helm, London.

Islam MR, Das B, Baruah D, Biswas SP, Gupta A. 2013. Fish diversity and fishing gears used in the Kulsi river of Assam, India. Ann Biol Res 4: 289-293.

Islam MZ, Rahmani AR. 2004. Important Bird Areas in India: Priority sites for conservation. Bombay Natural History Society and Birdlife International, UK.

Ismvael VA. 2019. Otter: Occurence in North East India. In: Choudhury A. (ed.) Natural History of North East India vol-1, Rashmi Prakash, India.

IUCN 2007. IUCN Red List of Threatened Species-Extinction crisis escalates. Biodiversity 8: 17-26.

IUCN 2020. The IUCN Red List of Threatened Species. Version 2020-2. https://www.iucnredlist.org. Assessed on 9 September 2020.

Jain SK, Rao RR. 1977. A handbook of field and herbarium methods. Today and Tomorrow's Printers and Publishers, New Delhi.

Javed S, Qureshi Q, Rahmani AR. 1999. Conservation status and distribution of swamp francolin in India. J Bombay Nat Hist 96: 16 23.

Kahl MP. 1971. Observation on the breeding of storks in India and Ceylon. J Bombay Nat Hist Soc 67: 453-461.

Kakati R, Tamuli JD. 2019. Diversity of Turtle and Tortoise Speciesin Nagshankar Temple, Biswanath, India. In: Hazarika AK. Ecology Environment and Conservation. ALA Publications, Guwahati.

Kanjilal VN, Kanjilal PC, Das A, De RN, Bor NL. 1934-1940. Flora of Assam, I-V. Government Press, Shillong.

Kar D, Nagarathna AV, Ramachandra TV, Dey SC. 2007. Fish diversity and conservation aspects in an aquatic ecosystem in Northeastern India. Zoos' Print J 21: 2308-2315.

Kasuya T, Haque AKMA. 1972. Some information on the distribution and seasonal movement of the Ganges dolphin. Sci Rep Whales Res Inst 24: $109-115$.

Khan MAR. 1987. Bangladesh Bonyoprani. Vol.I. Urochor o Shorishrip. Bangla Academy, Dhaka.

Khan MS. 2006. Amphibians and Reptiles of Pakistan. Krieger Publication, Florida.

Khan WA, Qasimi M, Ahmed E, Akbari G, Habib AH, Ali H, Mueen F, Chaudhury AA, Iqbal S, Bhaagat HB, Akhtar M, Shafiq A. 2007. A survey of Smooth Coated Otters (Lutrogale perspicillata sindica) in the Sindh Province Of Pakistan. IUCN Otter Specialist Group Bull 26: $15-32$.

Krivenko VG, Vinogradov VG, Green A, Perennou C. 1994. Ferruginous Duck Aythya nyroca. In: Tucker GM, Heath MF. (eds.) Birds in Europe: their conservation status. BirdLife International, Cambridge.

Kumar G, Kaur A, Maan SG. 2019. Study on Status and health of wetlands in India: A geographical analysis. Our Heritage 67: 188-198.

Lahkar BP. 2000. The Assam Roofed Turtle Kachuga sylhetensis in Kaziranga National Park-a new locality record. Hamadryad 25: 208 210.

Lambert MRK. 1984. Amphibians and reptiles. In: Cloudsley-Thompson JL. (ed) Key Environments: Sahara Desert. Pergamon Press, London.

Lekagul B, Round PD. 1991. A guide to the birds of Thailand. Saha Karn Bhaet, Bangkok.

Mackenzie MJS. 1985. Diary of M.J.S. Mackenzie: Visit to India April (1985). Unpublished report to the Wildfowl and Wetlands Trust, Slimbridge, U.K.

Mahanta M, Saikia PK, Saikia MK. 2019. Avifaunal Assemblages of Jhanjimuk-Kokilamukh IBA Complex of Jorhat Assam India-A Potential Ramsar Site of Assam. Appl Ecol Environ Sci 7: 101-109.

Maheswaram G, Rahmani AR, Coulter M. 2004. Recent records of Blacknecked Stork Ephippiorhynchus asiaticus in India. Forktail 20: 112 116.

Mason CF, Macdonald SM. 1986. Otters, Ecology and Conservation. Cambridge University Press, UK.

Mathew R, Sen N. 2010. Pictorial Guide to Amphibians of North East India. Zoological Survey of India, Kolkata.

Mazumder MK, Boro F, Barbhuiya B, Singha U. 2014. A study of the winter congregation sites of the Gangetic River Dolphin in southern Assam, India, with reference to conservation. Global Ecol Conserv 2: 359-366.

McGowan PJK, Dowll SD, Carroll JP, Aebischer NJ. 1995. Partridges, quails, francolins, snowcocks, and guineafowl: status survey and conservation action plan, 1995-1999. IUCN, Gland.
McGowan PJK, Rahmani AR, Iqbal P. 1994. Swamp francolin conservation project. World Pheasant Assoc News 46: 19-20.

Medhi K, Chakraborty R, Upadhyay J. 2014. Photographic record of Smooth-Coated Otter (Lutrogale perspicillata Geoffroy 1826) in Nyamjang Chu Valley, Arunachal Pradesh, India. IUCN/SCC Otter Specialist Group Bull 31: 75-79.

Meylan PA. 1987. The phylogenetic relationships of soft-shelled turtles (family: Trionychidae). Bull Am Mus Nat Hist 186: 1-101.

Mirza MR, Ali A. 1992. Amphibians and Chelonians of Lahore. Biologia 19: 82-87.

Mitsch WI, Gosselink IG. 1986. Wetlands. Van Nostrand Reinhold, New York

Mohan RSL, Dey SC, Bairagi SP. 1998. On a residential dolphin population of the Ganges river dolphin, Platanista gangetica in the Kulsi river (Assam), a tributary of Brahmaputra. J Bombay Nat Hist Soc 95: 1-7.

Moll EO. 1987. Survey of the freshwater turtles of India. Part II. The genus Kachuga. J Bombay Nat Hist Soc 84: 7-25.

Moreno P. 2003. Ganges and Indus dolphins. In: Hutchins M, Kleiman D, Geist V, Murphy J, Thoney D. (eds) Grzimek's Animal Life Encyclopedia, vol. 15, 2nd ed. Gale Group, Farmington Hills.

Narayanan SP, Sreekumar B, Vijayan L. 2006. Breeding of the Oriental White Ibis Threskiornis melanocephalus at Kumarakom heronry (Kerala, India). Indian Birds 2: 150-151.

Neog P, Bordoloi R. 2016-2017. Changing pattern of weather and climatic condition in Biswanath District: A case study. In: Upadhyaya S. (ed) Atobi. Nature's Bonyopran, Bedeti.

Ngasepam RS, Shomorendra M, Kar D. 2015. A checklist of fish species diversity of Sone beel, the biggest wetland of Assam. NeBIO 6: 2126.

Nowak R. 1999. Walker's Mammals of the World, vol. 2. The Johns Hopkins University Press, Baltimore.

Nowak R. 2003. Walker's Marine Mammals of the World, vol. 2. The Johns Hopkins Univesity Press, Baltimore.

POWO. 2019. Plants of the World Online. Facilitated by the Royal Botanic Gardens, Kew. http://www.plantsoftheworldonline.org. [23 June 2020]

Prasad SN, Ramachandra TV, Ahalya N, Sengupta T, Kumar A, Tiwari AK, Vijayan VS, Vijayan L. 2002. Conservation of wetlands of Indiaa review. Trop Ecol 43: 173-186.

Praschag P, Gemel R. 2002. Identity of Black Soft-shell turtle Aspideretes nigricans (Anderson, 1875), with remarks on related species. Faunistische Abhandlungen, Museum für Tierkunde Dresden 23: 87116.

Praschag P, Hundsdorfer AK, Fritz U. 2008. Further specimens and phylogenetic position of the recently described leaf turtle species Cyclemys gemeli (Testudines: Geoemydidae). Zootaxa 1: 29-37.

Purkayastha J, Das M, Sengupta S. 2011. Urban herpetofauna: a case study in Guwahati City of Assam, India. Herpetol Notes 4: 195-202.

Purkayastha J, Roychoudhury S, Biswa BB, Das M, Sengupta S. 2020. Herpetofaunal diversity and conservation status in Amchang Wildlife Sanctuary of Assam, India. In: Roy N, Roychoudhury S, Nautiyal S, Agarwal S, Baksi S. (eds.) Socio-economic and Eco-biological Dimensions in Resource use and Conservation. Springer Nature, New York.

Purkayastha J. 2013. An amateur's guide to reptiles of Assam. EBH Publisher, Guwahati.

Qaiser H, Sharma DK. 2016. Diversity and Distribution of Turtles in Central valley of Manipur, India. Intl J Biol Sci 5: 45-52.

Rahmani AR, Islam MZ. 2008. Duck, Geese, and Swans of India: Their Status and Distribution. Oxford University Press, India

Rahmani AR, Narayan G, Rosalind L. 1990. Status of Greater adjutant stork (Leptoptilos dubius) in the Indian Subcontinent. Colonial Waterbirds 13: 138-142.

Rahmani AR, Qamar M. 1993. Status and distribution of swamp francolin in India. In: Jenkins D. (ed.) Pheasants in Asia. World Pheasant Association, United Kingdom.

Rahmani AR, Singh B. 1996. White-necked or Woolly-necked Stork Ciconia episcopus (Boddaert) nesting on cliffs. J Bombay Nat Hist Soc 93: 293-294.

Rahmani AR. 1989. Status of the Black-necked Stork Ephippiorhynchus asiaticus in the Indian subcontinent. Forktail 5: 99-110.

Raj M, Deka J, Bhattacharya PC. 1989. Observations on the behavior of sub-adult Black-necked Storks at Dipor Beel, Assam. Newslett Birdwatchers 29: 7-8 
Ramsar Convention Secretariat. 2007. Wise use of wetlands: A conceptual framework for the wise use of wetlands. Ramsar Convention Secretariat, Gland.

Ramsar Secretariat. 2013. The List of Wetlands of International Importance. The Secretariat of the Convention on Wetlands, Gland.

Rashid SMA, Swingland IR. 1997. On the ecology of some freshwater turtles in Bangladesh. In: Van Abbema J. (ed.) Proceeding: Conservation, Restoration, and Management of Tortoises and TurtlesAn International Conference. New York Turtle and Tortoise Society, New York.

Rashid SMA. 1991. On the systematic and ecology of some freshwater turtles of Bangladesh. [Dissertation]. University of Kent, Centerbury.

Rasmussen PC, Anderton JC. 2005. Birds of South Asia: The Ripley Guide, Vol 2. Smithsonian Institution and Lynx Educations, USA.

Reeves RR, Leatherwood S, Mohan RSL. 1993. A Future for Asian River Dolphins: Report from a Seminar on the Conservation of River Dolphins in the Indian Subcontinent. Whale and Dolphin Conservation Society, Wiltshire.

Reuther C, Dolch D, Green R, Jahrl J, Jefferies D, Krekemeyer A, Kucerova M, Madsen AB, Romanowski J, Roche K, Ruiz-Olmo J, Teubner J, Trindade A. 2002. Surveying and monitoring distribution and population trends of the Eurasian otter (Lutra lutra): guidelines and evaluation of the standard method for surveys as recommendec by the European section of the IUCN/SSC Otter Specialist Group. Habitat 12: 1-148.

Roberts TR. 1982. Systematics and geographical distribution of the Asian silurid catfish genus Wallago, with a key to the species. Copeia 4 : 890-894

Rolfe JK, McKenzie NL. 2000. Comparison of methods used to capture herpetofauna: an example from the Carnarvon Basin. Rec Western Austr Mus 61: 361-370.

Saikia B, Kharkongor IJ. 2017. Checklist of endemic amphibians of Northeast India. Rec Zool Surv India 117: 91-93.

Saikia J. 2017. Religion and Social Change among the Ethnic Communities of Assam. Intl J Interdisc Res Sci Soc Cult 3: 180-195.

Saikia PK, Bhattacharjya PC. 1989a. Adjutant Storks at risk in Assam, India. Ibises Spoonbills Newslett 2: 6-8.

Saikia PK, Bhattacharjya PC. 1989b. A study of the avifauna of Deepor beel, a potential bird sanctuary of Assam. In: Parish D, Prentice C (eds) Wetland and waterfowl conservation in Asia. International Waterfowl and Wetlands Research Bureau, Wageningen, Netherland.

Saikia PK. 1995. Ecobiology of adjutant storks with special references to Leptoptilos javanicus in the Brahmaputra valley, Assam. [Dissertation]. Gauhati University, Guwahati. [Indian]

Samant JS, Prakash V, Naoraji R. 1995. Ecology and behavior of resident raptors with special reference to endangered species, final report 1990-1993. Bombay Natural History Society, Mumbai.

Sanghal B, Raman L, Nair CA, Pandya P, Shirodkar G, Shaikh Q. 2014. The sanctuary guide to Kaziranga. Sel Print India Private Limited, Mumbai.

Sarma PK, Baruah C, Sharma DK. 2009a. Distribution and Conservation Status of Assam Roof turtle, Pangshura sylhetensis in Assam 12(1) 43-47. In: Freshwater Turtles and Tortoises of India, ENVIS Bulletin: Wildlife and Protected Areas. Dehradun, India.

Sarma PK, Borah R, Upadhaya S, Dutta S, Mahanta G. 2009b. A handbook of Behali Reserved Forest. Nature's Bonyopran, Assam.

Sarma S, Bhattacharjya BK, Ziadi SGS, Lange AT, Goswami M. 2004. Indigenous ornamental fish biodiversity of central Brahmaputra valley zone, Assam. J Inland Fish Soc India 36: 29-35.

Sarma SK, Borah B. 2014. Phytosociological investigation of aquatic macrophytes of five wetlands of Sonitpur district of Assam, India. Ann Biol Res 5: 38-45.
Scott DA, Rose PM. 1997. Atlas of Anatidae Populations in Africa and Western Eurasia. Wageningen, Netherland.

Scott DA. 1989. A directory of Asian wetlands. IUCN, Switzerland.

Shakya S, Shrestha AK, Kalsi RS. 2001. Distribution of the swamp francolin in the Terai grasslands of Nepal. In: Woodburn MIA, McGowan PJK, Carroll JP, Musavi AH, Zhang ZW (eds) Galliformes 2000: proceedings of the 2nd International Galliformes Symposium, Kathmandu, and Royal Chitwan National Park, Nepal. King Mahendra Trust for Nature Conservation and World Pheasant Association, 24th September-1 st October 2000.

Shannon CE, Weaver W. 1949. The Mathematical Theory of Communication. University of Illinois Press, Urbana, IL.

Sharma SK. 1988. A new record of the Assam Roofed Turtle, Kachuga sylhetensis (Jerdon) from the Manas Wildlife Sanctuary, Assam. J Bombay Nat Hist Soc 85: 623-624.

Shrestha TK. 1989. Biology, status, and conservation of the Ganges river dolphin, Platanista gangetica, in Nepal. In: Perrin WF, Brownell JRL, Zhou K, Liu J (eds) Biology and Conservation of the River Dolphins, IUCN Species Survival Commission, Vol. 3. IUCN, Gland, Switzerland.

Silva P, Khan WA, Kanchanasaka I, Lubis R, Feeroz MM, Al-Sheikhly OF. 2015. Lutrogale perspicillata, The IUCN Red List of Threatened Species. IUCN, Gland.

Snow DW, Perrins CM. 1998. The Birds of the Western Palearctic Vol 1 \& 2. Oxford University Press, United Kingdom.

FpSpace Applications Centre. 2011. National Wetland Atlas. Indian Space Research Organisation, Ahmedabad.

Talukdar BK, Das RK. 1997. Record of birds of prey in Nameri wildlife sanctuary, Assam. Newslett Birdwatchers 37: 50-51.

Talukdar BN, Sharma P. 1995. Checklist of the birds of Orang Wildlife Sanctuary. Guwahati, India.

Talwar PK, Jhingran AG. 1991. Inland Fishes of India and Adjacent Countries, vol. I and II. Oxford and IBH Co., New Delhi.

Thewlis RM, Timmins RJ, Evans TD, Duckworth JW. 1998. The conservation status of birds in Laos: A review of key species. Bird Conserv Intl 8: 1-159.

Tiwari JK, Rahmani AR. 1998. Large heronries in Kutch and the nesting of Glossy Ibis Plegadis falcinellus at Luna jheel, Kutch, Gujarat, India. J Bombay Nat Hist Soc 95: 67-70.

Turner RK, Van Der Bergh JCJM, Soderqvist T, Barendregt A, Van Der Straaten JE, Van Ierland EC. 2002. Ecological-economic analysis of wetlands: scientific integration for management and policy. Ecol Econ 35: 7-23.

Vaghela U, Sawant D, Bhagwat V. 2015. Woolly-necked Storks Ciconia episcopus nesting on mobile-towers in Pune, Maharashtra. Indian Birds 10: 154-155.

Vishwanath W. 2017. Diversity and conservation status of freshwater fishes of the major rivers of northeast India. Aquat Ecosyst Health Manag 20: 86-101.

Wakid A. 2005. Status and distribution of the endangered Gangetic dolphin (Platanista gangetica gangetica) in the Brahmaputra River within India. Curr Sci 97: 1143-1151.

Wakid A. 2006. Status and distribution of a newly documented residential Gangetic dolphin (Platanista gangetica Roxburgh 1801) population in eastern Assam. J Bombay Nat Hist Soc 102: 158-161.

Wetlands International 2006. Waterbird Population Estimates. $4^{\text {th }}$ ed. Wetlands International, Wageningen, The Netherlands.

Zedler JB, Kercher S. 2005. Wetland resources: Status, trends, ecosystem services, and restorability. Ann Rev Environ Res 30: 39-74. 